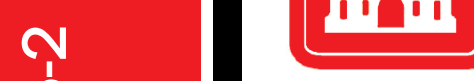

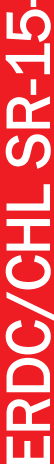

US Army Corps

of Engineers $s_{\circledast}$

Engineer Research and

Development Center

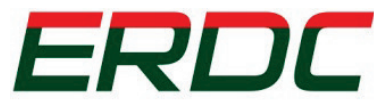

INNOVATIVE SOLUTIONS

for a safer, better world

\title{
Conceptual Regional Sediment Budget for USACE North Atlantic Division
}

Julie Dean Rosati, Ashley E. Frey,

Alison Sleath Grzegorzewski, Coraggio K. Maglio,

Andrew Morang, and Robert C. Thomas

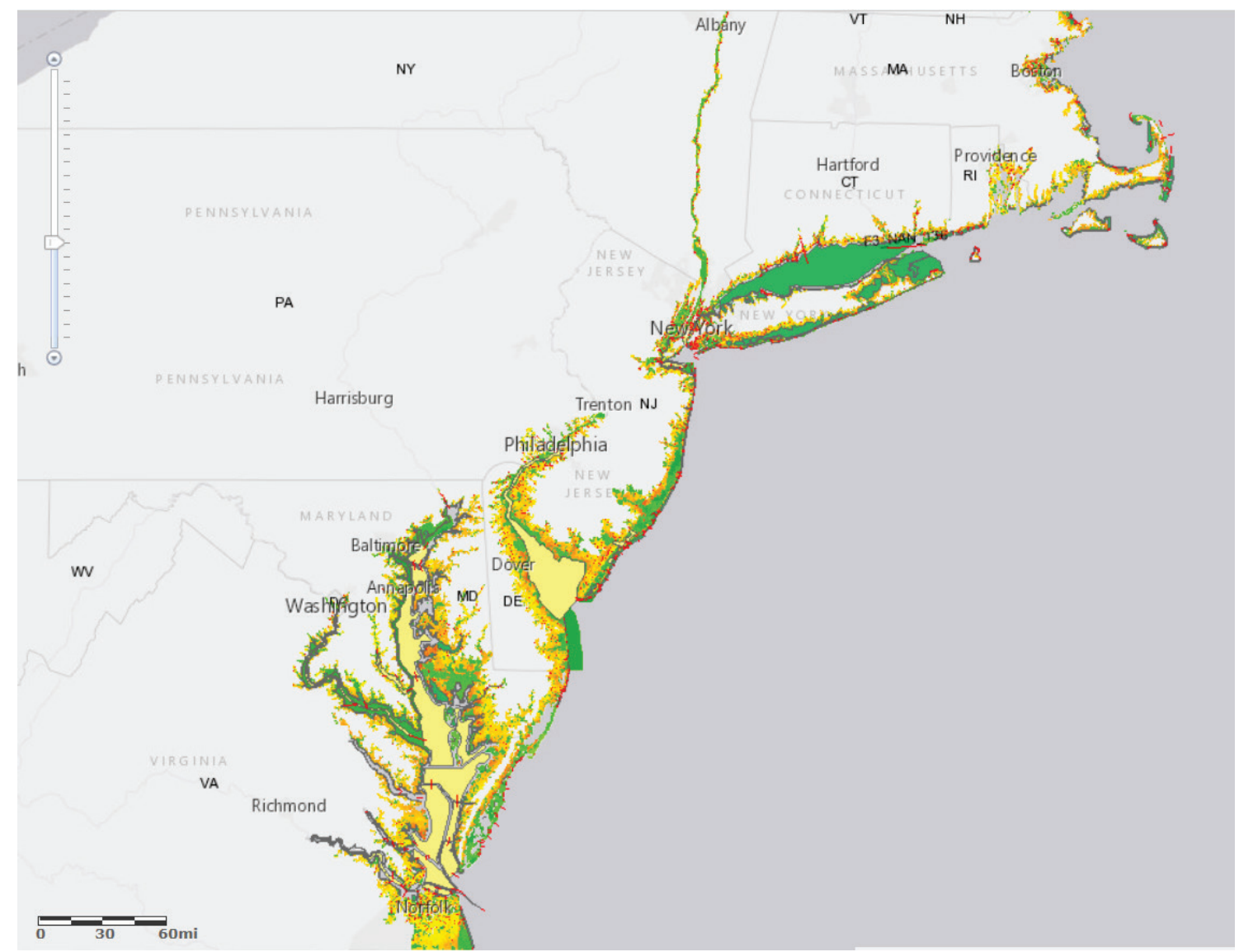


The US Army Engineer Research and Development Center (ERDC) solves the nation's toughest engineering and environmental challenges. ERDC develops innovative solutions in civil and military engineering, geospatial sciences, water resources, and environmental sciences for the Army, the Department of Defense, civilian agencies, and our nation's public good. Find out more at www.erdc.usace.army.mil.

To search for other technical reports published by ERDC, visit the ERDC online library at http://acwc.sdp.sirsi.net/client/default. 


\section{Conceptual Regional Sediment Budget for USACE North Atlantic Division}

Julie Dean Rosati, Ashley E. Frey, Alison Sleath Grzegorzewski, Coraggio K. Maglio, Andrew Morang, and Robert C. Thomas

Coastal and Hydraulics Laboratory

U.S. Army Engineer Research and Development Center 3909 Halls Ferry Road

Vicksburg, MS 39180-6199

Final report

Approved for public release; distribution is unlimited.

Prepared for USACE North Atlantic Division 302 General Lee Avenue Brooklyn, NY 11252 


\section{Abstract}

This report documents development of a conceptual regional sediment budget (CRSB) for the U.S. Army Corps of Engineers (USACE), North Atlantic Division (NAD). The NAD requested preparation of a CRSB as part of the post-Hurricane Sandy assessment to provide information about sediment sources and opportunities for strategic placement of sediment within the Division. Development of a detailed working sediment budget is fundamental to better sediment management. A conceptual sediment budget is the first phase in development of the working budget and is intended to provide a general framework based on existing transport information from which a more detailed sediment budget can be later prepared based on rigorous data analysis and numerical modeling. For this CRSB, existing literature and databases were reviewed and analyzed to characterize sediment transport pathways and magnitudes, and morphologic zones of erosion and accretion. The CRSB highlights areas with data gaps, conflicts in existing budgets, and opportunities for better sediment management within the NAD and is available via a geographic information system (GIS) portal.

DISCLAIMER: The contents of this report are not to be used for advertising, publication, or promotional purposes. Citation of trade names does not constitute an official endorsement or approval of the use of such commercial products. All product names and trademarks cited are the property of their respective owners. The findings of this report are not to be construed as an official Department of the Army position unless so designated by other authorized documents. 


\section{Contents}
Abstract ii
Figures and Tables........................................................................................................................................
Preface .......................................................................................................................................................

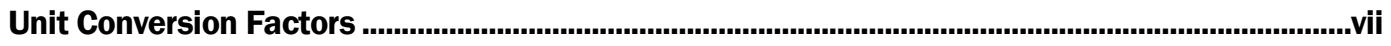

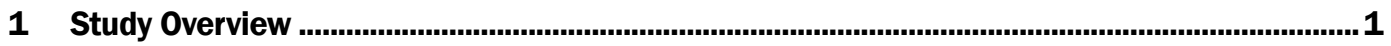
1.1 Conceptual regional sediment budget ............................................................. 2

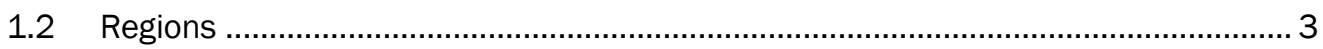

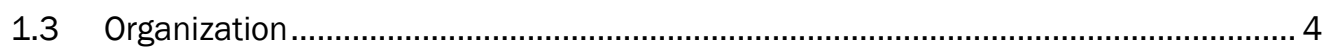

2 Region 1: Virginia-North Carolina Border to Chincoteague Inlet, MD ................................... 5

2.1 Description of region ............................................................................... 5

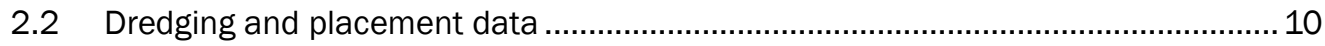

2.3 Recommendations .......................................................................................... 11

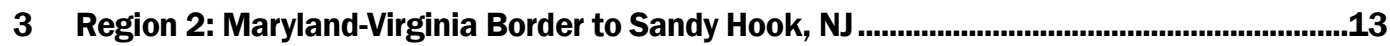

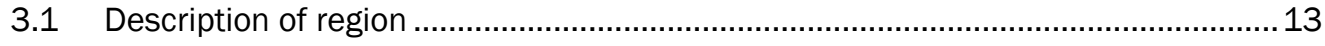

3.2 Dredging and placement data .................................................................. 16

3.3 Recommendations ................................................................................. 17

4 Region 3: Sandy Hook, NJ, to Connecticut-Rhode Island Border ..........................................19

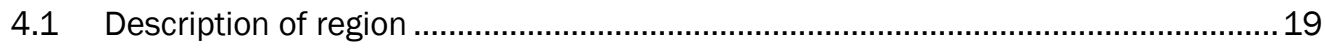

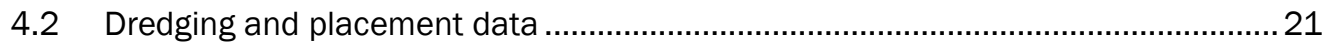

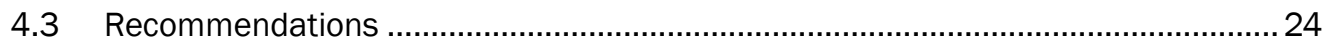

5 Region 4: Connecticut-Rhode Island Border through Maine...................................................26

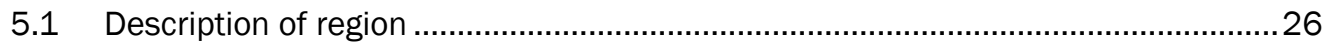

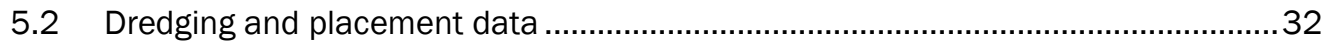

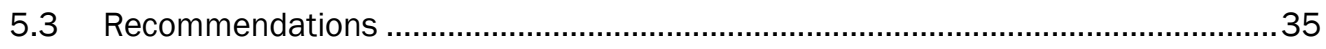

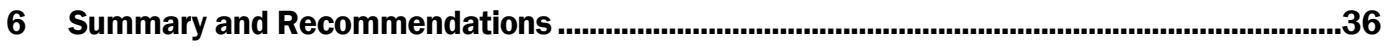

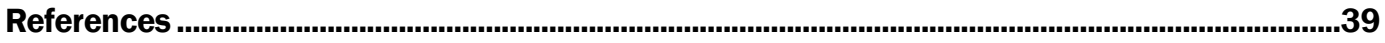

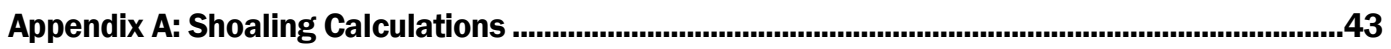

\section{Report Documentation Page}




\section{Figures and Tables}

\section{Figures}

Figure 1. Path of Hurricane Sandy and Regions defined for the CRSB.

Figure 2. General net sediment transport pathways for Region 1 (includes NACCS planning regions VA1 through VA6 and MD2 through MD5).

Figure 3. CRSB for Region 1, extending from the southern to northern borders of Virginia along the Atlantic Ocean, including Chesapeake Bay; colors indicate erosion, accretion, or stability (no change)/no data in the cell (fluxes not shown for clarity).

Figure 4. Detail of CRSB for Region 1: Entrance to Chesapeake Bay showing cells and fluxes (red arrows).

Figure 5. CRSB for Region 1 showing confidence levels (fluxes not shown for clarity).

Figure 6. CRSB for Region 1 showing the composite exposure Index, cell gain/loss (left) and cell confidence (right); regions with both high exposure and erosion/low confidence are identified.

Figure 7. General net sediment transport pathways for Region 2 including NACCS planning regions MD1, DE1 through DE3, and NJ2 through NJ4.

Figure 8. CRSB for Region 2, extending from Maryland-Virginia border to Sandy Hook, NJ; colors indicate erosion, accretion, or stability (no change) or no data in the cell (fluxes not shown for clarity).

Figure 9. Detail of CRSB for Region 2: Ocean City Inlet, MD.

Figure 10. CRSB Region 2 showing confidence levels (fluxes not show for clarity).

Figure 11. CRSB for Region 2 showing composite exposure indicies, cell gain/loss (left) and cell confidence (right); regions with both high expsoure and erosion/low confidence are identified.

Figure 12. General net sediment transport pathways for Region 3, incorporating NACCS planning regions NJ1, NY-NJ1, NY1 through NY4, and CT1.

Figure 13. CRSB for Region 3, extending from Sandy Hook, NJ, to the Connecticut-Rhode Island border; colors indicate erosion, accretion, or stability (no change) or no data in the cell (fluxes not shown for clarity).

Figure 14. Detail of CRSB for Region 3: from East Rockaway Inlet to Fire Island Inlet, NY................21

Figure 15. CRSB for Region 3 showing confidence levels.

Figure 16. CRSB for Region 3 showing composite exposure indices, cell gain/loss (upper) and cell confidence (lower); regions with both high exposure and erosion/low confidence are identified.

Figure 17. General net sediment transport directions for Region 4, including NACCS planning regions RI1 and RI2, MA1 through MA5, NH1, and the state of Maine to the Canadian border.

Figure 18. Region 4 CRSB from Rhode Island through Massachusetts; colors indicate erosion, accretion, or stability (no change) or no data in the cell (fluxes not shown for clarity).

Figure 19. Detail of CRSB for Region 4: vicinity of Cape Cod, MA. ...................................................28

Figure 20. Region 4 CRSB showing confidence levels and coverage. 
Figure 21. CRSB for Region 4 showing composite exposure indices, cell gain/loss (left) and cell confidence (right); regions with both high exposure and erosion/low confidence are identified.

Figure 22. Sand spits on Cape Cod are fed by till bluffs at a rate of approximately 916,000 yd 3 /yr (from Giese et al. (2011)).

Figure 23. Rockport Peninsula, Massachusetts, showing isolated pocket beaches along the south shore and Essex River beach and shoal complex to the north. Essex River flux values in cubic yards per year from Smith and FitzGerald (1994).

Figure 24. Mouth of the Kennebec River and beaches at Popham Beach State Park (flux pathways from Goldschmidt et al. (1991) and FitzGerald and Fink (1987)).

Figure 25. Overall summary of CRSB showing locations that had good-quality sediment budget data.

\section{Tables}

Table 1. DIS dredging data for Region 1 from 1990 to present (July 2013) for both contract and USACE dredges.

Table 2. DIS dredging data for Region 2 from 1990 to present (July 2013) for both contract and USACE dredges.

Table 3. DIS dredging data for Region 3 from 1990 to present (July 2013) for both contract and USACE dredges.

Table 4. DIS dredging data for Region 3 from 1990 to present (July 2013) for both contract and USACE dredges: data with 1-2 entries.

Table 5. DIS dredging data for Region 4 from 1990 to present (July 2013) for both contract and USACE dredges.

Table 6. DIS dredging data for Region 4 from 1990 to present (July 2013) for both contract and USACE dredges: data with 1-3 entries. 34

Table 7. Dredging and placement volumes for Region 4 from sources other than DIS. 


\section{Preface}

This report documents preparation of a conceptual regional sediment budget (CRSB) which is viewable via a geographic information system (GIS) map portal*. The report was prepared by the following team: Ashley E. Frey, Coastal Engineering Branch (CEB), Navigation Division (ND), Coastal and Hydraulics Laboratory (CHL); Alison Sleath Grzegorzewski, Coastal Processes Branch (CPB), Flood and Coastal Division (FD), CHL; Coraggio Maglio, CEB, ND, CHL; Dr. Andrew Morang, CEB, ND, CHL; Dr. Julie Dean Rosati, CPB, FD, CHL; and Robert C. Thomas, CEB, ND, CHL. Funding was provided from the post-Hurricane Sandy Comprehensive Study, administered through the Baltimore District of NAD. Tanya Beck and Linda Lillycrop, CEB, ND, and Mark Gravens, CPB, FD, CHL, provided peer review of this report. The work described in the report was performed under the general administrative supervision of Tanya Beck, Chief of CEB; Mark Gravens, Chief of CPB; Dr. Jackie Pettway, Chief, ND; and Dr. Ty Wamsley, Chief of FD. José E. Sánchez and Dr. Kevin Barry were Director and Deputy Director of CHL, respectively, during the preparation of the report.

At the time of this study, COL Jeffrey R. Eckstein was Commander of ERDC. Dr. Jeffery P. Holland was ERDC Director. 


\section{Unit Conversion Factors}

\begin{tabular}{|l|l|l|}
\hline Multiply & By & To Obtain \\
\hline cubic yards & 0.7645549 & cubic meters \\
\hline feet & 0.3048 & meters \\
\hline yards & 0.9144 & meters \\
\hline
\end{tabular}




\section{Study Overview ${ }^{1}$}

On behalf of the U.S. Army Corps of Engineers (USACE) North Atlantic Division (NAD), the USACE Baltimore District (NAB) collaborated with the Engineer Research and Development Center (ERDC), Coastal and Hydraulics Laboratory (CHL) to develop a conceptual regional sediment budget (CRSB) for NAD. This task was initiated as a component of the Comprehensive Hurricane Sandy study in response to Hurricane Sandy, which generated remarkable beach erosion and property damage throughout NAD as it traveled up the Atlantic Coast and made landfall on 30 October 2012 near Brigantine, NJ. Formulation of a CRSB is the first step in understanding sediment transport patterns and magnitudes and aligning dredging and placement operations to take advantage of natural processes and identifying sediment deficiencies in a regional system.

The area of focus for the CRSB was the coastal watersheds extending from Virginia to Maine. Optimizing regional sediment management practices in these areas is critical to (a) improving beneficial use and placement of dredged sediments; (b) providing storm protection and environmental enhancement/restoration; and (c) reducing USACE costs in maintaining coastal infrastructure. The CRSB team was formed to rapidly respond to NAD's request to complete the study within a 3-month period. The CRSB leveraged existing ERDC tools and research from the Dredging Operations and Environmental Research (DOER) program, Regional Sediment Management (RSM) Program, and Coastal Inlets Research Program (CIRP), databases from the Institute for Water Resources (IWR), as well as prior work for regional sediment management in the North Atlantic. The CRSB is viewable via a geographic information system (GIS) map portal'2. This report summarizes the methods and databases utilized in preparation of the CRSB and is intended to document data represented in the CRSB portal.

\footnotetext{
1 This chapter was written by Julie Dean Rosati and Ashley Frey.

2 CRSB GIS portal: https://geoplatform.usace.army.mil/home/webmap/viewer.html?webmap=f50f2b8ba08d4b4c915b4 44a25ee3d06. If the link from this pdf does not load the CRSB data, cut and paste the link into a web browser.
} 


\subsection{Conceptual regional sediment budget}

A CRSB documents patterns and rates of sediment transport, engineering activities such as dredging and placement, and volumetric change for coastal and estuarine regions (Dolan et al. 1987; Kana and Stevens 1992). The CRSB was developed in the Sediment Budget Analysis System (SBAS) for rapid dissemination and viewing by NAD and stakeholders.

A conceptual sediment budget is the first phase in development of a working budget and is intended to provide a general framework based on existing transport information from which a more detailed sediment budget can be prepared based on more rigorous data analysis and numerical modeling. For the CRSB, existing sediment budgets, literature, and District databases were reviewed and analyzed to characterize sediment transport pathways and magnitudes and morphologic zones of erosion and accretion.

A sediment budget is an accounting of gains (sources), losses (sinks), and sediment-related engineering activities within a specific control volume (sediment budget cell) or a series of cells across a given period of time (Bowen and Inman 1966; Caldwell 1966; Rosati 2005). Cells are typically defined by morphology, engineering activities, coastal structures, or known sediment transport fluxes. As with any accounting system, the algebraic difference between sediment sources and sinks in each cell, hence for the entire sediment budget, must equal the rate of change in sediment volume within that region, accounting for possible engineering activities. Expressed in terms of variables either as volume or as volumetric rate of change, the sediment budget equation is

$$
\sum Q_{\text {source }}-\sum Q_{\text {sink }}-\Delta V+P-R=\text { Residual }
$$

where $Q_{\text {source }}$ and $Q_{\operatorname{sink}}$ are the sources and sinks of sediment to the control volume, respectively; $\Delta V$ is the volume change within the cell; $P$ and $R$ are the placement and removal of sediment within the cell, respectively; and Residual is the degree to which the cell is balanced. Ideally, the Residual is zero, meaning that the cell is balanced. For the CRSB, nonzero Residuals were found in many cells and were retained in the sediment budgets to indicate conflicts in information available or a lack of data. 
Confidence levels were assigned to each morphologic zone based on whether a sediment budget was available (high confidence); only general information existed for volume change, sediment pathways, or magnitudes (medium confidence); or only qualitative observations of morphology from aerial imagery were available to provide general sediment transport pathways (low confidence). Dredging information available from the Dredging Information System (DIS) database ${ }^{1}$ for both USACE and contract dredging from 1990 through July 2013 were analyzed to provide representative average annual infilling rates for USACE navigation channels. The CRSB highlights areas with data gaps, conflicts in existing budgets, and opportunities for better sediment management within the NAD.

\subsection{Regions}

To prepare the CRSB, the coastal watersheds from Virginia to Maine were divided into regions as follows (Figure 1):

- Region 1 extends from the southern border of NAD (VA-NC border) to the VA-MD border and includes the North Atlantic Coast Comprehensive Study (NACCS) planning regions VA1 through VA6 and MD2 through MD5.

- Region 2 extends from just north of Chincoteague Inlet, VA, to Sandy Hook, NJ, including NACCS planning regions MD1, DE1 through DE3, and NJ2 through NJ4.

- Region 3 extends from Sandy Hook, NJ, to the CT-RI border, covering NACCS planning regions NJ1, NY-NJ1, NY1 through NY4, and CT1.

- Region 4 extends from the CT-RI border to the northern border of Maine with Canada, including NACCS planning regions RI1 and RI2, MA1 through MA5, and NH1 including the state of Maine to the Canadian border.

The division of regions was made based on geology and present-day morphology. 
Figure 1. Path of Hurricane Sandy and Regions defined for the CRSB.

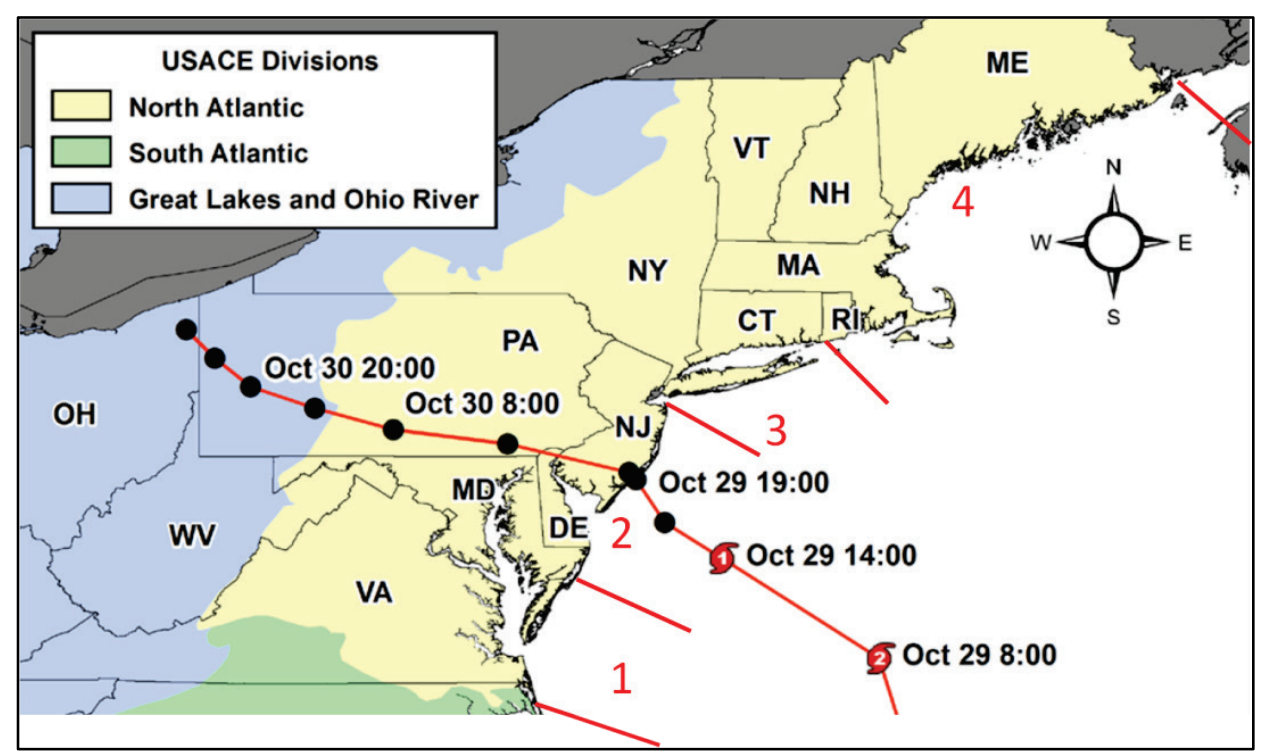

\subsection{Organization}

This report is organized into six chapters and one appendix as follows:

- Chapter 1 was written by Julie Dean Rosati and Ashley Frey and provides an overview of the study and describes general sediment budget concepts.

- Chapters 2 through 5 describe the CRSB developed for each region:

- Chapter 2 was written by Robert C. Thomas and Ashley Frey, for Region 1.

- Chapter 3 was written by Alison Sleath Grzegorzewski and Ashley Frey, for Region 2.

- Chapter 4 was written by Julie Dean Rosati and Ashley Frey, for Region 3.

- Chapter 5 was written by Andrew Morang and Ashley Frey, for Region 4.

- Chapter 6 was written by the entire team to summarize the study and provide final recommendations.

- Appendix A details the dredging analysis and was written by Coraggio Maglio and Robert C. Thomas. 


\section{Region 1: Virginia-North Carolina Border to Chincoteague Inlet, MD1}

\subsection{Description of region}

Region 1 of the CRSB extends from the Virginia-North Carolina border to the Virginia-Maryland border along the Atlantic Coast and includes the Chesapeake Bay and tributaries. This region encompasses NACCS planning regions VA1 through VA6 and MD2 through MD5. In general, sediment is transported towards the bay from the Atlantic shorelines and into the bay from the Susquehanna River and other rivers (Figure 2).

Sediment is deposited into the bay and lower portions of the tributaries.

Figure 2. General net sediment transport pathways for Region 1 (includes NACCS planning regions VA1 through VA6 and MD2 through MD5).

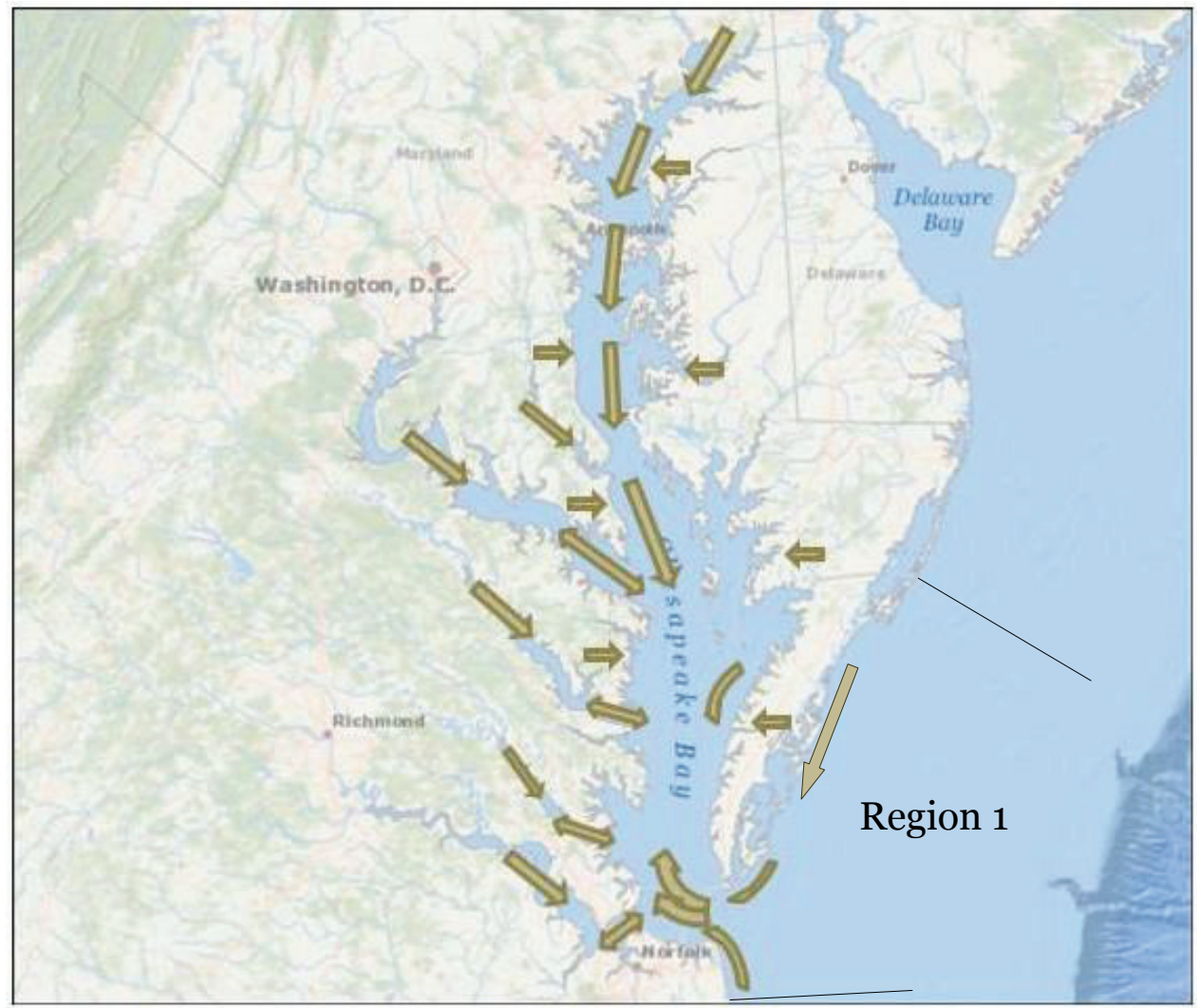

Existing sediment budgets were available along the east end of Wallops Island (King and Ward 2010; Morang et al. 2006), but largely absent along

\footnotetext{
1 This chapter was written by Robert C. Thomas and Ashley Frey.
} 
the Atlantic Coast. Wave climate and littoral transport have been studied in the vicinity of Rudee Inlet and Virginia Beach (Briggs and Thompson 2008; USACE, Norfolk District 2006), but a complete sediment budget was not readily available. Van Gaalen (2004) presents potential longshore transport calculated using hindcast wave data and compares these calculations to limited measurements by others. The magnitudes of reported potential transport rates are not included in the CRSB, but the direction of transport is shown along the Atlantic Coast based on van Gaalen (2004) in the absence of data.

The Chesapeake Bay portion of the CRSB includes all of the tidal rivers. Major rivers include the James, Elizabeth, Nansemond, York, Rappahannock, Potomac, Patuxent, and Susquehanna. Dozens of smaller rivers and creeks are also included. Sediment budgets were previously calculated for the York, Patuxent, and Potomac Rivers (Herman and Friedrichs 2010; Herman 2012). Sediment processes, including sediment load from some major rivers such as the Susquehanna, were summarized by the U.S. Geological Survey (USGS 2003). A large scale sediment budget for the Chesapeake was developed by Hobbs et al. (1990, 1992). This Chesapeake sediment budget compared bathymetric surveys to estimate change in volume across the bay in large cells. Herein, assumptions were made in the CRSB to split those larger cells into the smaller cells required for this budget so that the navigation channels were differentiated from bay cells (Figure 3 ).

The CRSB supports the general understanding of erosion and accretion shown in Figure 2, in that bay shorelines are primarily erosive and sediment is depositing in the bays, tributaries, and navigation channels. Some bay shores are stable either from hardening with revetments, seawalls, or protection from coastal structures such as detached breakwaters, or through beach nourishment. Virginia coastal cells are stable because of beach nourishment whereas the coastal cells along southern Maryland to just north of Chincoteague have not had beach nourishment and are erosional.

Cells were added as placeholders for reaches in which there were no available data. Shoreline change data for the Atlantic Coast from Hapke et al. (2010) and for the Chesapeake Bay from the Virginia Institute of Marine Science (VIMS 2013) for select Chesapeake Bay shorelines were applied to estimate volume change in cells for which other higher confidence data or 
calculations were not available. These estimates are suitable to be used qualitatively to investigate trends until more reliable analyses can be conducted. The sediment budget portal facilitates viewing zooming in and out (see Figure 4 for an example). Confidence levels were provided for each cell as shown in Figure 5; low confidence levels indicate that there are no data for these locations. The majority of cells had low confidence levels with a few along the shorelines having medium confidence levels.

Figure 3. CRSB for Region 1, extending from the southern to northern borders of Virginia along the Atlantic Ocean, including Chesapeake Bay; colors indicate erosion, accretion, or stability (no change)/no data in the cell (fluxes not shown for clarity).

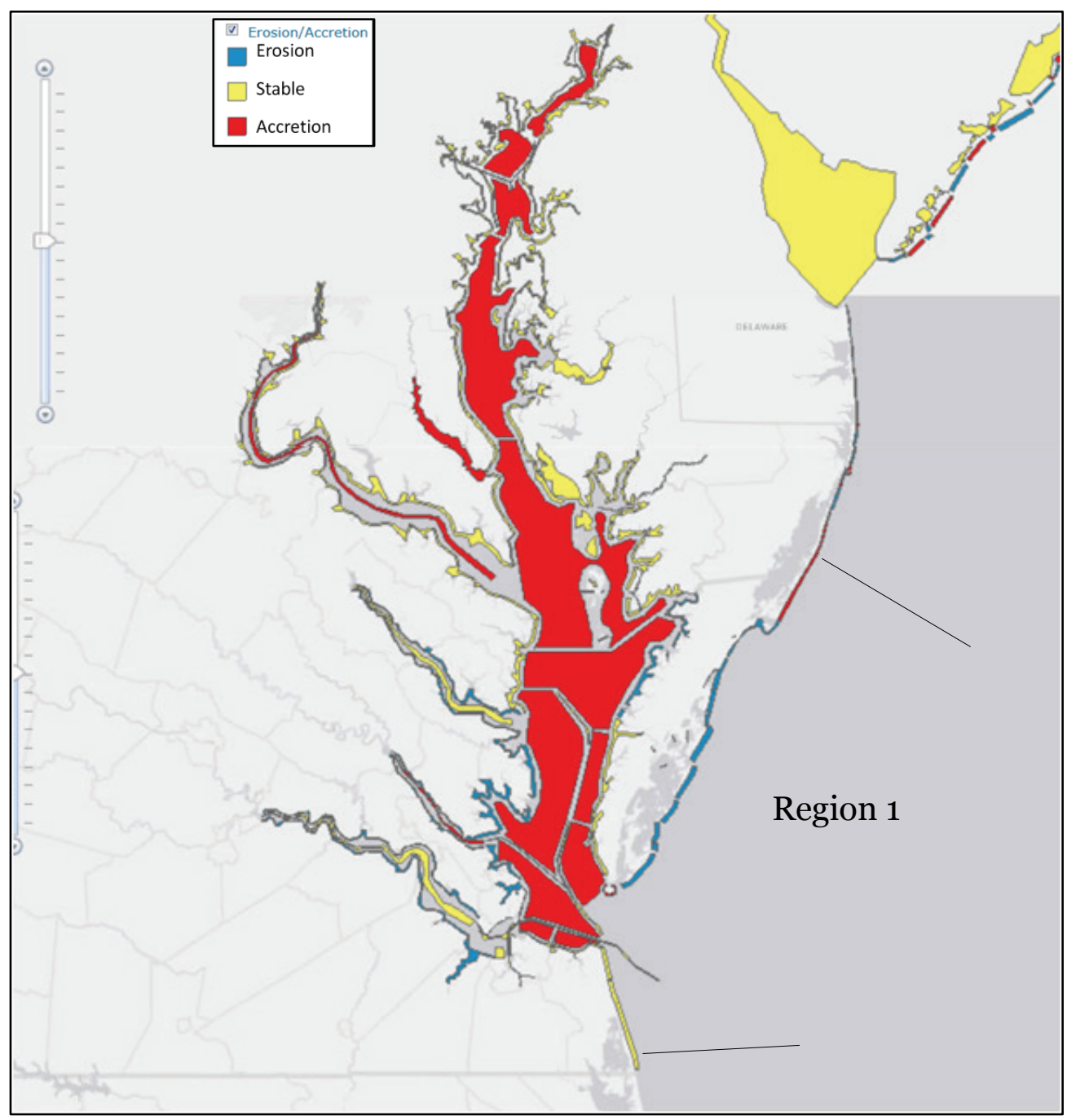


Figure 4. Detail of CRSB for Region 1: Entrance to Chesapeake Bay showing cells and fluxes (red arrows).

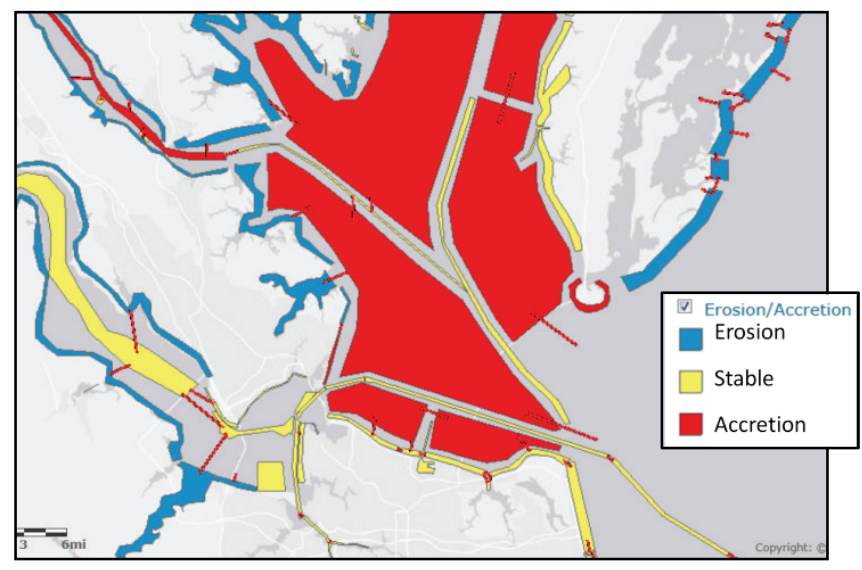

Figure 5. CRSB for Region 1 showing confidence levels (fluxes not shown for clarity).

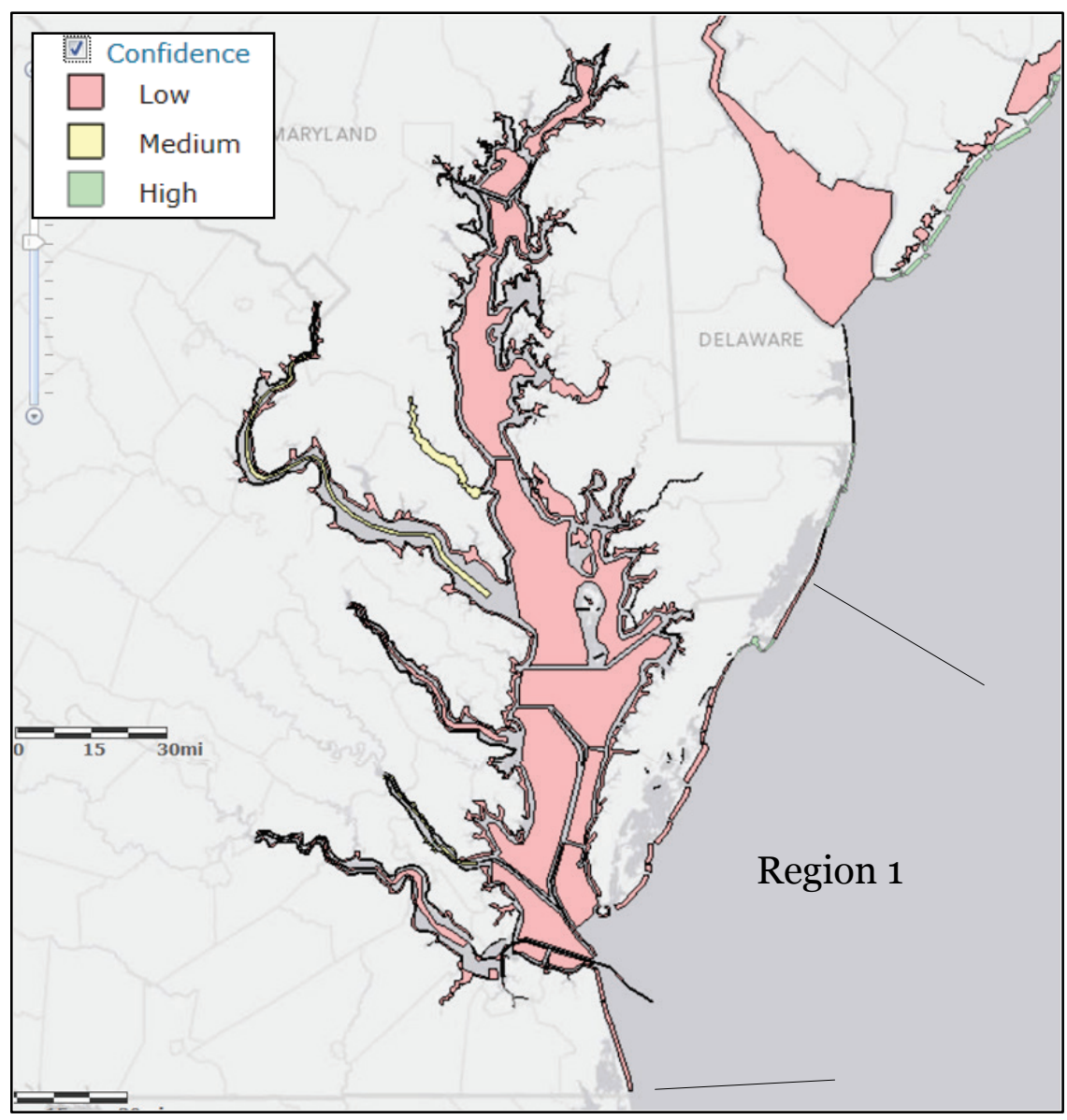


The NAD provided ${ }^{1}$ a composite exposure index that combines three exposure layers: infrastructure and population (80\% weighting), social vulnerability (10\% weighting), and environmental exposure (10\% weighting). Infrastructure and population includes critical infrastructure (e.g., hospitals, emergency response facilities) and population density. Social vulnerability emphasizes older, younger, and lower-income populations. Environmental exposure provides greater weighting to endangered habitat and wetlands. Figure 6 shows the Region 1 sediment budget (left) and confidence (right) with the composite exposure index, with areas of higher exposure and erosion/low confidence identified. Note that some cells are shown as stable because these locations have ongoing beach nourishment maintenance (e.g., Virginia Beach area) or there is insufficient data, as indicated by low confidence.

Figure 6. CRSB for Region 1 showing the composite exposure Index, cell gain/loss (left) and cell confidence (right); regions with both high exposure and erosion/low confidence are identified.

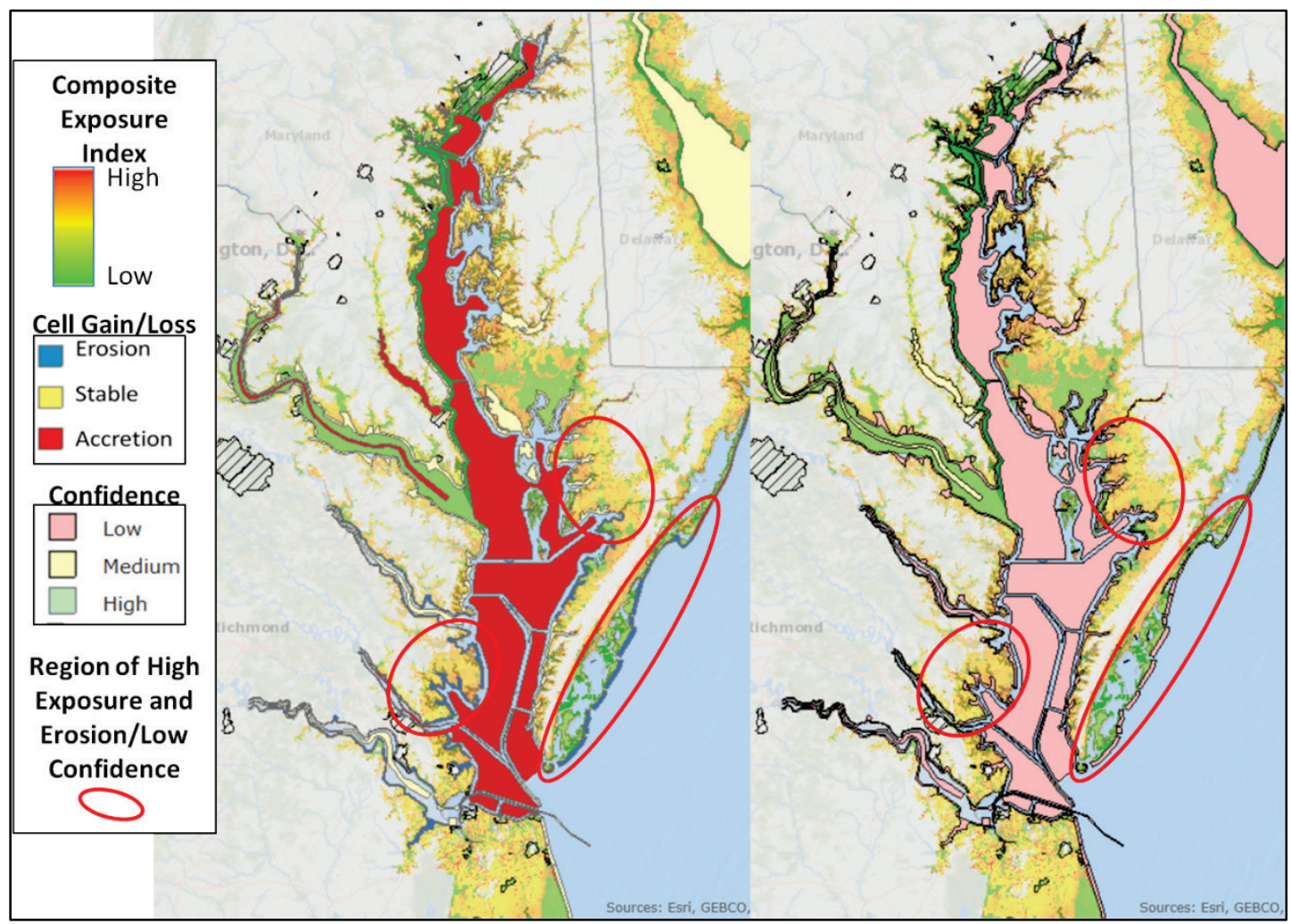

1 POCs: David Robbins, James P. Green, and J. B. Smith, NAB. 


\subsection{Dredging and placement data}

This region had DIS (USACE 2015) dredging data available for 31 navigation channels and harbors for both contract and USACE dredges. All dredging data in the DIS were assumed to be Operation \& Maintenance (O\&M) (i.e., no New Work quantities). No placement data were available from DIS and were not included in the CRSB unless already incorporated within existing sediment budgets. On average, the DIS data indicated that the NAB and USACE Norfolk District (NAO) dredged 6.3 million cubic yards per year (yd $3 / \mathrm{yr}$ ) of littoral sediment within this region (Table 1). In Table 1, "Total" is the total volume recorded in the DIS; "Total Days" indicates the number of days between the start date and end date of dredging; "Chan ID" is the unique 4-digit channel identification identifier; and "Annual Rate" is the average annual dredging volume for that channel.

Table 1. DIS dredging data for Region 1 from 1990 to present (July 2013) for both contract and USACE dredges.

\begin{tabular}{|c|c|c|c|c|c|}
\hline Job Name & Total, yd $\mathbf{y}^{3}$ & $\begin{array}{l}\text { Total } \\
\text { Days }\end{array}$ & $\begin{array}{c}\text { Chan } \\
\text { ID }\end{array}$ & $\begin{array}{c}\text { Annual } \\
\text { Rate, yd }{ }^{3}\end{array}$ & Notes \\
\hline Honga River, MD & 508,235 & 6,804 & 2487 & 27,264 & \\
\hline Poplar Island & $3,587,961$ & 3,935 & 2494 & 332,810 & Poplar Island Construction \\
\hline Nanticoke River, DE & 129,867 & 8,387 & 2507 & 5,652 & \\
\hline Chester River, MD & 90,186 & 5,132 & 2513 & 6,414 & \\
\hline Pocomoke River, MD & 160,231 & 5,083 & 2525 & 11,506 & \\
\hline Fishing Creek & 120,895 & 7,815 & 2534 & 5,646 & \\
\hline Herring Bay, MD & 64,413 & 5,327 & 2535 & 4,414 & \\
\hline Knapps Narrows, MD & 121,834 & 3,496 & 2539 & 12,720 & \\
\hline Wicomico River & $1,163,296$ & 7,324 & 2554 & 57,974 & \\
\hline Baltimore Harbor, MD & $49,853,100$ & 7,517 & 2557 & $2,420,697$ & Distribution of channel dredging unclear \\
\hline Cape Henry - York Spit & $51,483,769$ & 6,120 & 4716 & 511,960 & York Spit collated in analysis \\
\hline Little Wicomico River & 83,185 & 7,304 & 5164 & 4,157 & \\
\hline Starlings Creek & 113,159 & 3,782 & 3101 & 10,921 & \\
\hline Whitings Creek & 48,533 & 3,260 & 3103 & 5,434 & \\
\hline Greenvale Creek & 42,952 & 6,869 & 3106 & 2,282 & \\
\hline Queens Creek & 34,207 & 6,878 & 3107 & 1,815 & \\
\hline James River & $17,332,635$ & 8,258 & 3114 & 766,095 & \\
\hline LynnHaven & $1,011,646$ & 8,213 & 3117 & 44,959 & \\
\hline Chincoteague & 275,362 & 7,997 & 3118 & 12,568 & Using values from existing budget \\
\hline Norfolk Harbor Anchorage & $12,112,566$ & 8,125 & 3120 & 544,134 & Anchorage and Channel not split in CRSB \\
\hline Hoskins Creek & 178,987 & 7,027 & 3129 & 9,297 & \\
\hline
\end{tabular}




\begin{tabular}{|l|l|l|l|l|l|}
\hline \multicolumn{1}{|c|}{ Job Name } & \multicolumn{1}{|c|}{ Total, $\mathbf{y d}^{3}$} & $\begin{array}{c}\text { Total } \\
\text { Days }\end{array}$ & $\begin{array}{c}\text { Chan } \\
\text { ID }\end{array}$ & $\begin{array}{c}\text { Annual } \\
\text { Rate, } \mathbf{y d}^{3}\end{array}$ & \multicolumn{1}{|c|}{ Notes } \\
\hline Tangier Channel & 274,416 & 7,638 & 3135 & 13,114 & \\
\hline Pagan River & 78,808 & 5,510 & 3155 & 5,220 & \\
\hline Thimble Shoal Channel & $4,971,549$ & 7,395 & 3158 & 245,384 & \\
\hline Chincoteague Inlet (Inner) & $1,341,309$ & 6,599 & 3168 & 74,190 & Using values from existing budget \\
\hline Rudee Inlet & $1,510,444$ & 8,339 & 3177 & 66,112 & \\
\hline Bennetts Creek & 43,902 & 7,786 & 3178 & 2,058 & \\
\hline Chincoteague Harbor of Refuge & 22,214 & 6,607 & 3188 & 1,227 & Using values from existing budget \\
\hline Norfolk Harbor & $6,454,292$ & 4,670 & 4318 & 504,458 & Anchorage and Channel not split in CRSB \\
\hline Craney Island Rehandling Basin & $10,611,907$ & 7,262 & 4331 & 533,372 & Not included in CRSB \\
\hline Channel to Newport News & 789,317 & 4,633 & 5136 & 62,184 & \\
\hline \multicolumn{7}{|l|}{ Average Annual Rate for Region } & & \\
\hline
\end{tabular}

Channel locations were either adopted from the National Channel Framework (NCF) or, because many channels for Region 1 are not yet available in the $\mathrm{NCF}$, approximated based on online information.

\subsection{Recommendations}

Of the 243 cells that have been created to characterize this region, most cells were not balanced (i.e., nonzero residuals), and approximately 130 cells were created as placeholders and had no data. Many areas had at least some data, primarily shoreline change data. The Maryland portion of Chesapeake Bay was the most sparsely populated area within this region. Sediment transport pathways within the bay have been summarized by Hobbs et al. (1990), but more detailed analysis is needed for engineering applications at a local scale.

Within Region 1, the following are recommended to improve understanding of sediment transport and, ultimately, regional sediment management practices:

- The Virginia Beach area has been nourished longer than most other projects in the nation; updating the sediment budget in this area should be a priority during the next beach nourishment design.

- Many of the Chesapeake Bay sediment budgets were reported in units of metric tons per year. Gross assumptions were used for conversion to 
cubic yards per year in the CRSB. Those assumptions should be updated during a more rigorous analysis.

- Over half of the Chesapeake Bay shorelines did not have shoreline change data available. The USGS (2003) noted that shoreline erosion is a large contributor to sediment in the Bay. VIMS is currently analyzing shoreline change for the remainder of the Bay. As data are made available, the CRSB should be updated.

- Shoreline change data that were available may have been based on historical conditions prior to shoreline armoring. Recent armoring would change future shoreline change. Future analyses should investigate this potential source of error.

- Most references indicate that the net transport of sediment is from the ocean and Susquehanna River into the Bay, then into the tributaries, making the Bay and tributaries sediment traps. Further analysis should be conducted to determine temporal patterns in sediment transport directions to help better inform management options. 


\section{Region 2: Maryland-Virginia Border to Sandy Hook, NJ1}

\subsection{Description of region}

Region 2 of the CRSB extends from the Maryland-Virginia border at the south to Sandy Hook, NJ, at the north, including NACCS planning regions MD1, DE1 through DE3, and NJ2 through NJ4. Net sediment transport patterns for Region 2 are shown in Figure 7, with two nodal zones ${ }^{2}$ located approximately at the Delaware-Maryland border and between Barnegat Inlet and Shark River Inlet.

Figure 7. General net sediment transport pathways for Region 2 including NACCS planning regions MD1, DE1 through DE3, and NJ2 through NJ4.

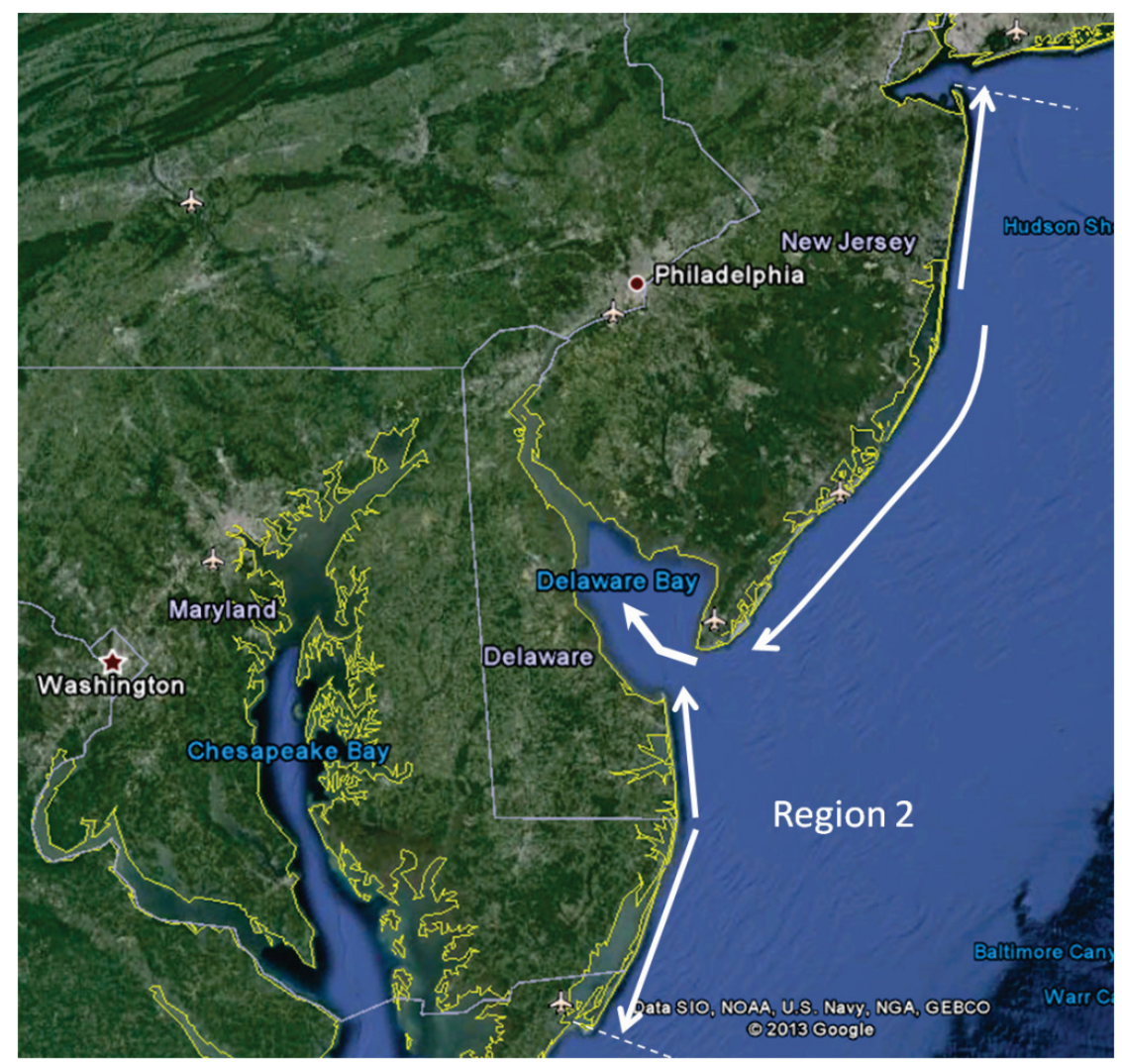

\footnotetext{
1 This chapter was written by Alison Sleath Grzegorzewski and Ashley Frey.

2 An area in which the predominant direction in longshore sediment transport changes; gross transport (left- and right-directed transport) can still be large, but the net transport (difference between rightand left-directed transport) is approximately zero. Nodal zones typically migrate seasonally and yearly.
} 
This region includes the Atlantic coast of Maryland, Delaware, and a significant portion of coastal New Jersey. Existing sediment budgets were available for Assateague Island and Ocean City, MD (Offshore \& Coastal Technologies, Inc. 2011); Rehoboth Beach and Dewey Beach, DE (USACE, Philadelphia District 1996); and Cape May through Sandy Hook, NJ (USACE, New York District 2006; USACE, Philadelphia District 2006). Cells were added as placeholders for coastal reaches, estuaries, and bays in which there were no available data (Figure 8). A detailed image of the budget in the vicinity of Ocean City Inlet, MD, is shown in Figure 9.

Figure 10 shows confidence levels associated with each cell. Cells with low confidence represent gaps in knowledge.

Figure 8. CRSB for Region 2, extending from Maryland-Virginia border to Sandy Hook, NJ; colors indicate erosion, accretion, or stability (no change) or no data in the cell (fluxes not shown for clarity).

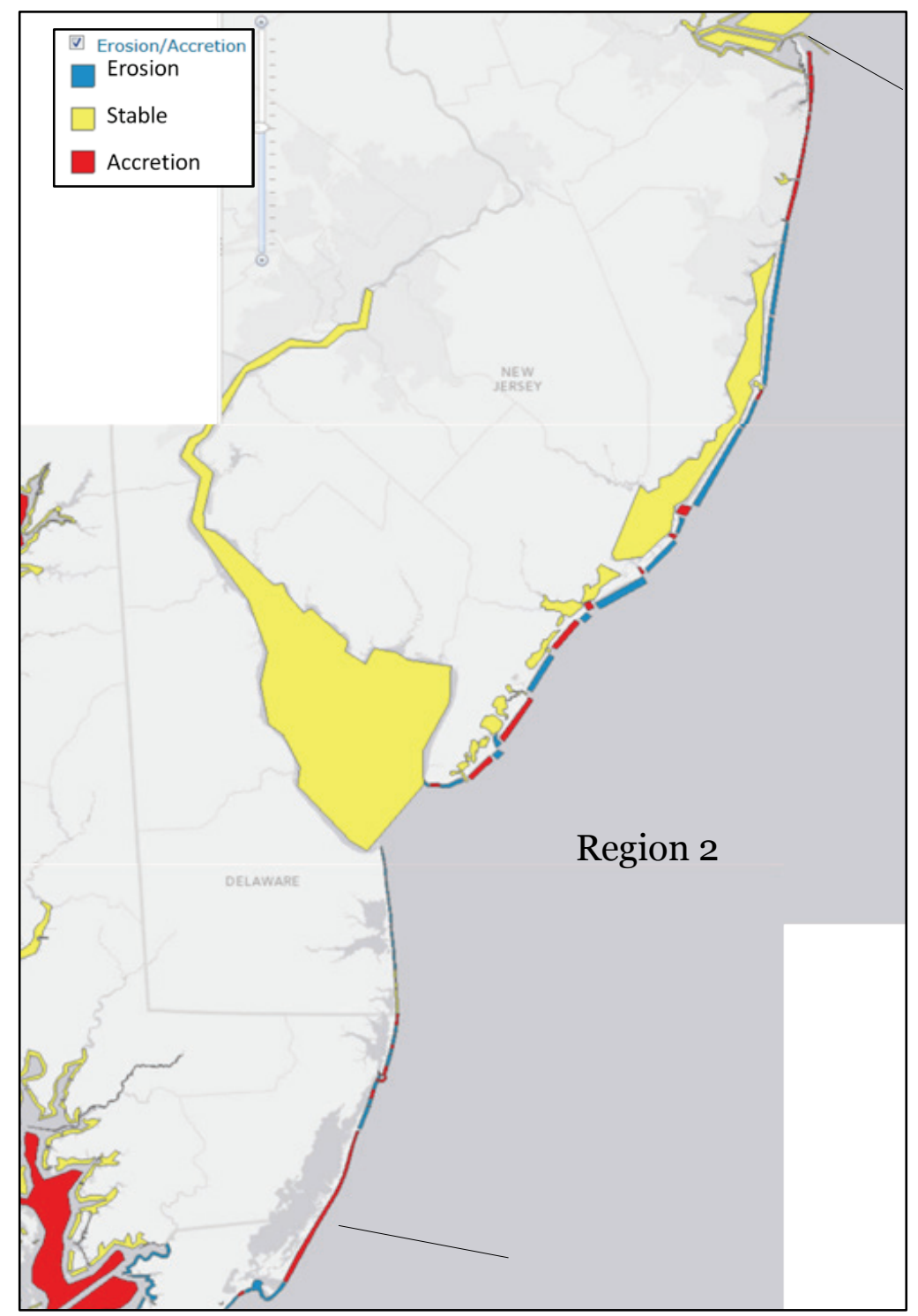


Figure 9. Detail of CRSB for Region 2: Ocean City Inlet, MD.

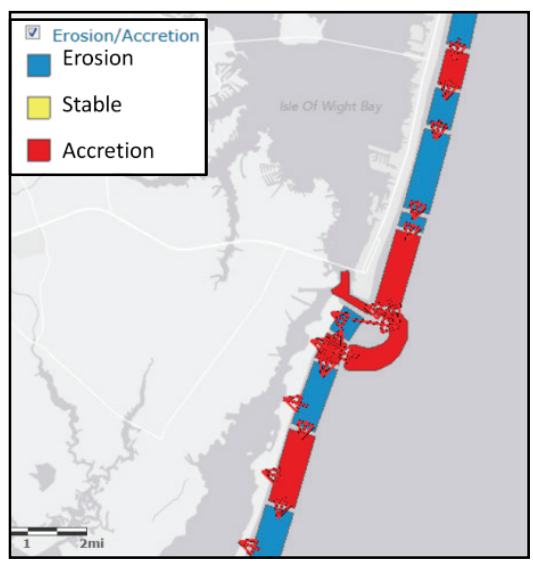

Figure 10. CRSB Region 2 showing confidence levels (fluxes not show for clarity).

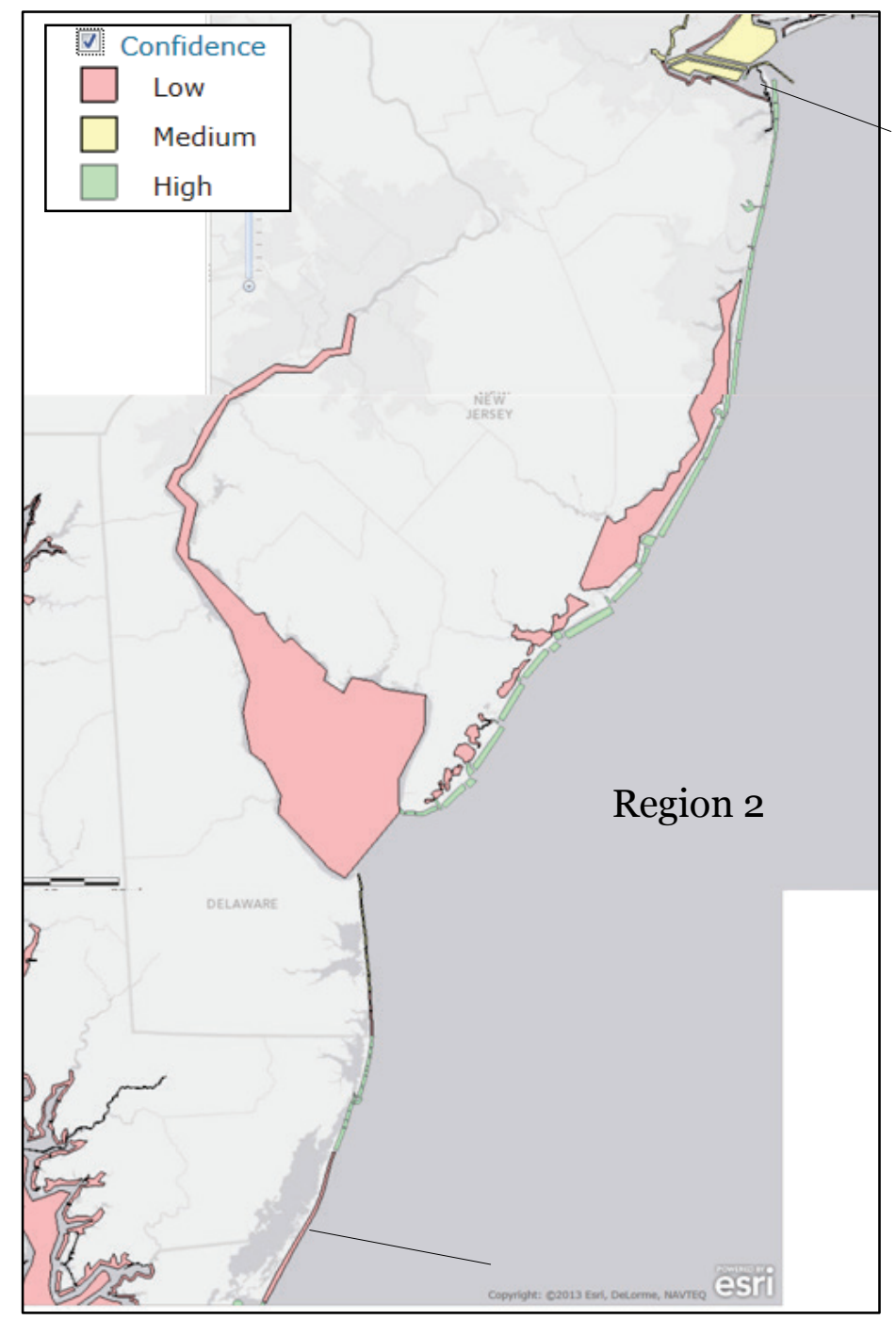


The composite exposure index provided by NAD is shown for Region 2 in Figure 11, with areas having high exposure indices and erosion and/or low confidence identified. Note that cells showing as stable (left) may not have data as indicated by low confidence (right); little information was discovered for any of the bays, including Delaware Bay.

Figure 11. CRSB for Region 2 showing composite exposure indicies, cell gain/loss (left) and cell confidence (right); regions with both high expsoure and erosion/low confidence are identified.

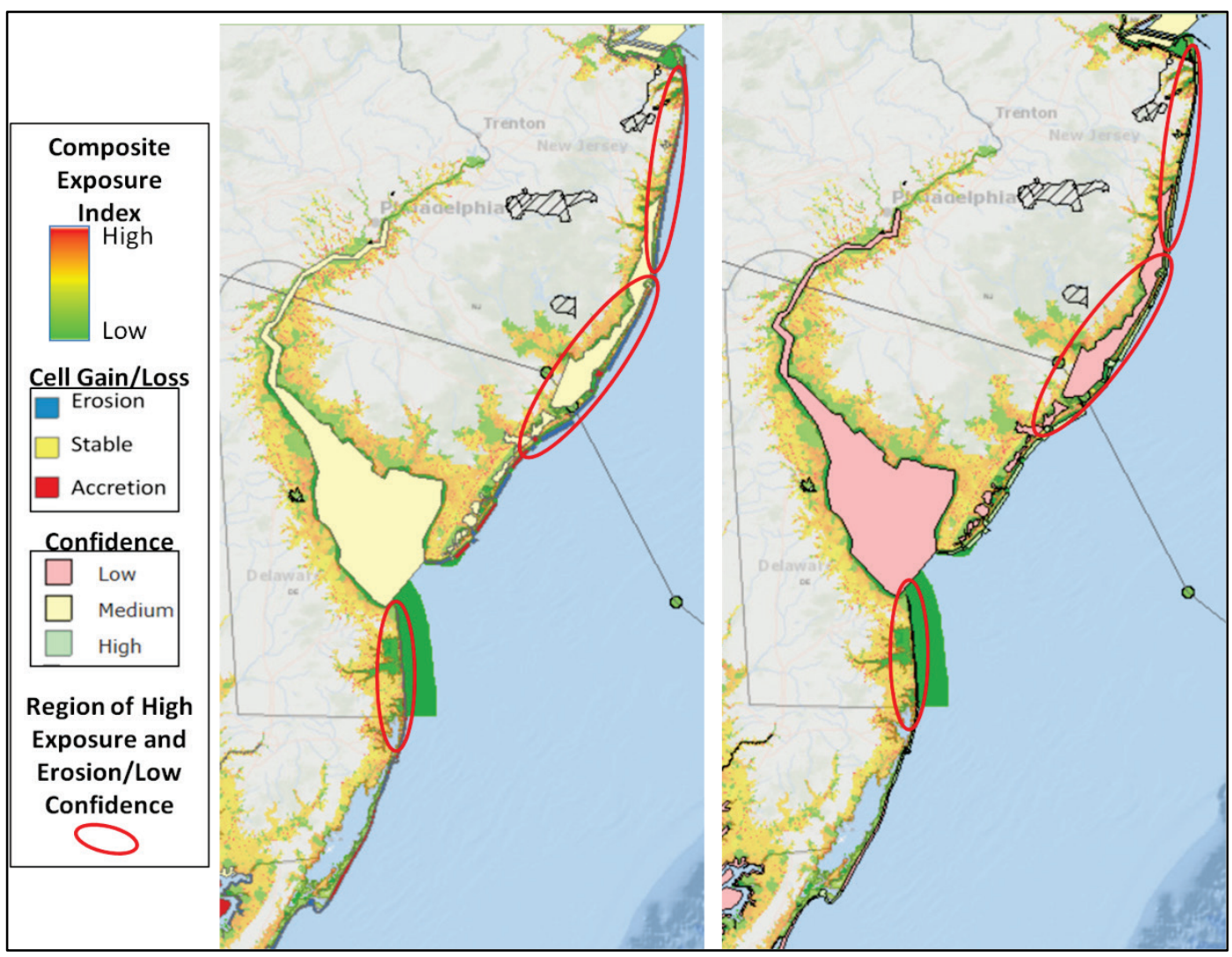

\subsection{Dredging and placement data}

Region 2 had dredging data for 19 navigation channels and harbors within the DIS for both contract and USACE dredges. All dredging data in the DIS were assumed to be O\&M (i.e., no New Work quantities). No placement data were available from DIS and were not included in the CRSB unless already incorporated within existing sediment budgets. On average, the DIS data indicated that 7.3 million $\mathrm{yd}^{3}$ of sediment was dredged within this region (Table 2). In Table 2, "Total" is the total volume recorded in the DIS, "Total Days" indicates the number of days between the start date and end date of dredging, "Chan ID" is the unique 4-digit channel identification identifier, and "Annual Rate" is the average annual dredging volume for that channel. 
Table 2. DIS dredging data for Region 2 from 1990 to present (July 2013) for both contract and USACE dredges.

\begin{tabular}{|l|l|l|l|l|l|}
\hline \multicolumn{1}{|c|}{ Job Name } & \multicolumn{1}{|c|}{$\begin{array}{c}\text { Total, } \\
\text { yd }^{3}\end{array}$} & Total Days & \multicolumn{1}{c|}{ Chan ID } & \multicolumn{1}{c|}{$\begin{array}{c}\text { Annual Rate, } \\
\text { yd }^{3}\end{array}$} & Notes \\
\hline Sandy Hook to Barnegat Inlet & $9,026,947$ & 6,051 & 5458 & 544,511 & \\
\hline Shark River & 374,366 & 6,039 & 3041 & 22,627 & \\
\hline Abesecon & $6,238,835$ & 2,919 & 4769 & 780,122 & \\
\hline Barnegat Inlet & $13,897,539$ & 8,641 & 4771 & 587,039 & \\
\hline Cape May - NJIWW & $7,393,153$ & 7,365 & 5056 & 366,395 & \\
\hline $\begin{array}{l}\text { Delaware River - } \\
\text { Philadelphia to Trenton }\end{array}$ & $3,055,523$ & 5,310 & 4783 & 210,031 & \\
\hline $\begin{array}{l}\text { Delaware River, Philadelphia } \\
\text { to Sea }\end{array}$ & $64,614,780$ & 8,158 & 4779 & $2,890,953$ & \\
\hline $\begin{array}{l}\text { Delaware River, Philadelphia } \\
\text { to Sea }\end{array}$ & $3,230,804$ & 4,916 & 5154 & 239,879 & \\
\hline $\begin{array}{l}\text { IWW Delaware River } \\
\text { Rehoboth Dewey Beach }\end{array}$ & $2,094,504$ & 3,714 & 4792 & 205,841 & \\
\hline Manasquan & 586,940 & 6,663 & 4798 & 32,153 & \\
\hline Mispillion River & 73,627 & 3,877 & 4801 & 6,932 & $\begin{array}{l}3 \text { records or } \\
\text { fewer }\end{array}$ \\
\hline Murderkill River & 208,631 & 4,374 & 4802 & 17,410 & \\
\hline NJIWW & $1,981,870$ & 7,825 & 4803 & 92,445 & \\
\hline Salem River & $1,069,287$ & 7,669 & 4807 & 50,892 & \\
\hline Schuylkill River & $2,848,571$ & 8,145 & 4808 & 127,652 & \\
\hline Wilmington Harbor & $13,935,361$ & 8,099 & 4814 & 628,029 & \\
\hline Assateague Island & $2,740,710$ & 5,544 & 2477 & 180,440 & \\
\hline Atlantic Coast of Maryland & $2,585,606$ & 4,420 & 4765 & 213,517 & \\
\hline Ocean City, MD & $2,104,699$ & 7,707 & 2522 & 99,678 & \\
\hline & & & & \\
\hline
\end{tabular}

Channel locations were either adopted from the NCF or, because most channels for Region 2 are not yet available in the NCF, approximated based on online information.

\subsection{Recommendations}

Of the 68 cells that have been created to characterize this region, 9 cells were not balanced, and 8 cells were created as placeholders and had no data. Areas with good sediment budget coverage include the Atlantic coast of Maryland, and the coast of New Jersey from Cape May through Sandy Hook (with the exception of the estuaries and bays). Studies to characterize sediment transport pathways and magnitudes for Bethany 
Beach and South Bethany, DE, as well as the estuaries and bays of New Jersey, were not discovered.

Within Region 2, the following are recommended to improve understanding of sediment transport and, ultimately, regional sediment management practices:

- Update the characterization of sediment sources and sinks for the Atlantic coast of Delaware. The source used to represent the sediment budget for this area was from 1996 and may not reflect present-day processes. In addition, the source used for this area did not include data for Bethany Beach and South Bethany, DE.

- Provide better characterization of the Delaware River tributaries. The Delaware River main channel Philadelphia-to-Sea was included in the CRSB, but not the nearby tributaries, even though data are available in the DIS (e.g., Salem River, Murderkill River, Mispillion River).

- Provide better characterization of the estuaries and bays in New Jersey. There may be improvements in sediment management that could be realized by comprehensive assessment of these estuaries and bays. 


\section{Region 3: Sandy Hook, NJ, to Connecticut- Rhode Island Border ${ }^{1}$}

\subsection{Description of region}

Region 3 of the CRSB extends from Sandy Hook, NJ, at the southern border to the Connecticut-Rhode Island border at the north, including New YorkNew Jersey Harbor and Long Island Sound and incorporating NACCS planning regions NJ1, NY-NJ1, NY1 through NY4, and CT1. Net sediment transport pathways are from east to west along the south shore of Long Island, directed towards New York-New Jersey Sound, with rivers feeding sediment to the Sound (Figure 12). Along the Connecticut coast (north shore of Long Island Sound), rivers provide sediment, and net transport is directed towards the west with local reversals. Along the northshore of Long Island, net transport is also to the west with local reversals. Long Island provides minimal fluvial sediment input to the Sound.

Figure 12. General net sediment transport pathways for Region 3, incorporating NACCS planning regions NJ1, NY-NJ1, NY1 through NY4, and CT1.

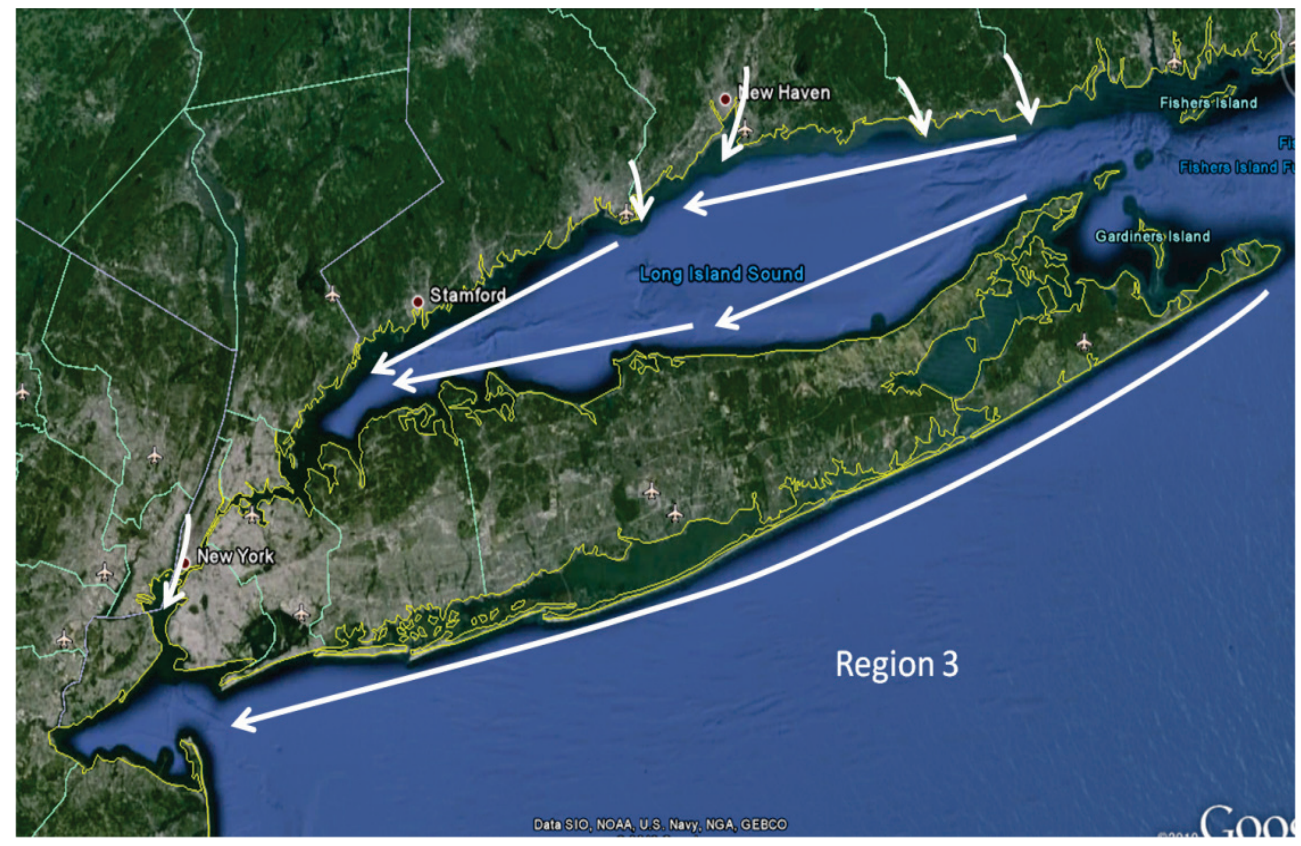

1 This chapter was written by Julie Dean Rosati and Ashley Frey. 
Existing sediment budgets were available for the estuarine shore of Sandy Hook (Silveira and Psuty 2009), the southwesterly facing ocean reach extending from Coney Island (Gravens et al. 1991; see also USACE New York District 1988, 1989) to Montauk Point (Moffat \& Nichol Engineers 1998, 2007; see also URS Group and Moffat \& Nichol Joint Venture 2010), except for the bays and estuaries. A few existing sediment budgets were available for several locations on the north shore of Long Island: Lake Montauk (Byrnes 2008), Mattituck Inlet (Batten and Kraus 2006), Mount Sinai Harbor (Offshore \& Coastal Technologies, Inc., East Coast 2010), and Asharoken (USACE, New York District 2004). General geologic information available for Long Island Sound Basin was utilized to document long-term sedimentation in the Sound (Lewis and DiGiacoco-Cohen 2000). Finegrained sources and sinks documented by Bokuniewicz and Ellsworth (1986) for New York Harbor and the Hudson-Raritan estuarine system were converted from metric tons per year to cubic yards per year with some gross assumptions about sediment type and porosity. The CRSB for Region 3 is shown in Figure 13. Figure 14 shows a zoomed-in image from East Rockaway Inlet to Fire Island Inlet. Confidence levels were entered for each cell (Figure 15); low confidence levels indicate that no data were available for these cells.

Figure 13. CRSB for Region 3, extending from Sandy Hook, NJ, to the Connecticut-Rhode Island border; colors indicate erosion, accretion, or stability (no change) or no data in the cell (fluxes not shown for clarity).

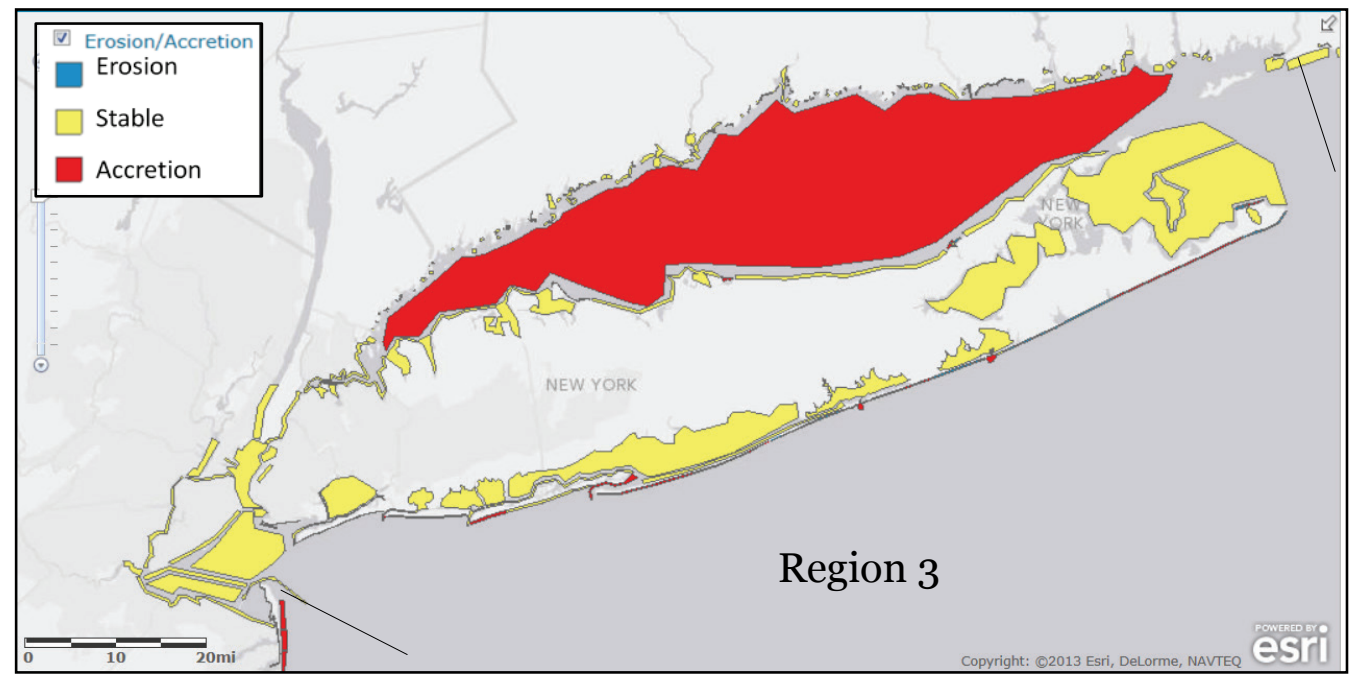


Figure 14. Detail of CRSB for Region 3: from East Rockaway Inlet to Fire Island Inlet, NY.

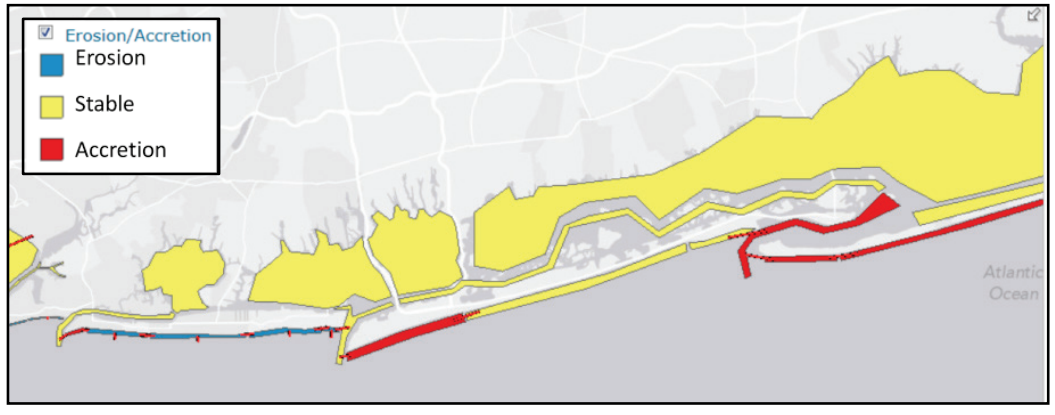

Figure 15. CRSB for Region 3 showing confidence levels.

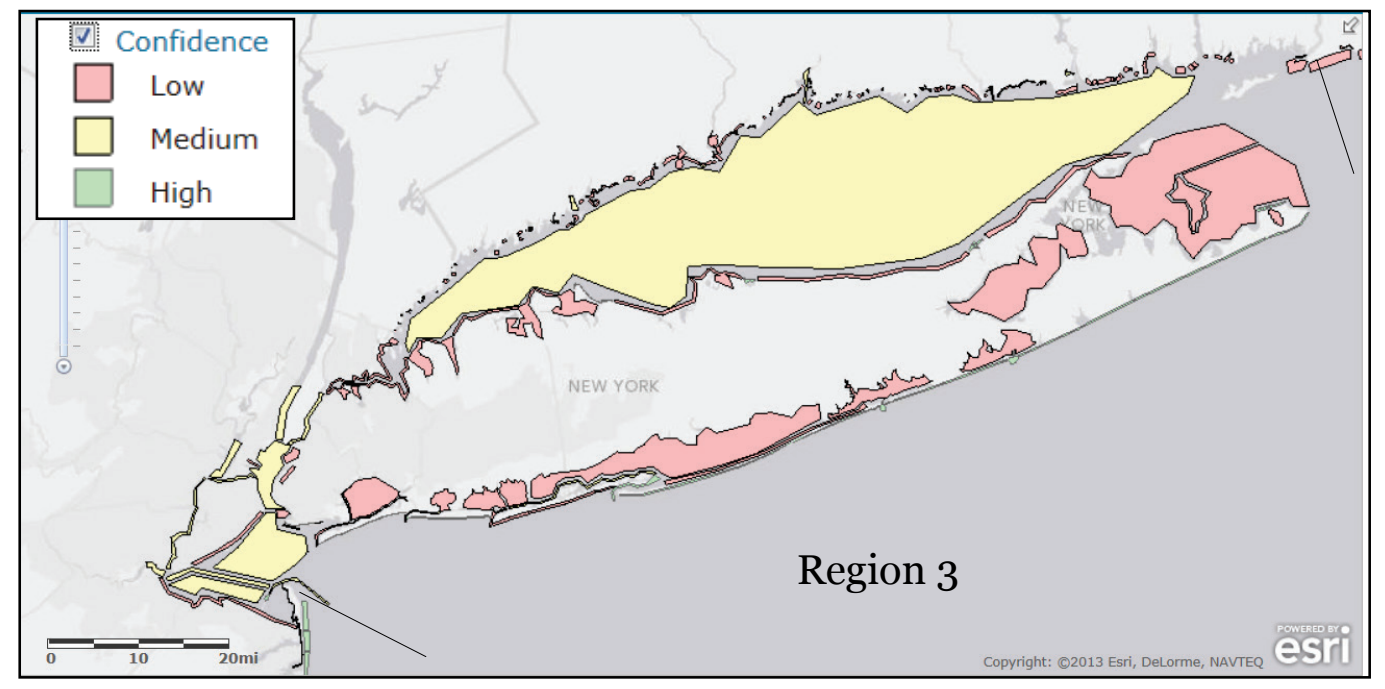

The composite exposure index provided by NAD is shown for Region 3 in Figure 16, with areas having both high exposure and erosion/low confidence identified. Cells showing as stable (top) may not have data as indicated by low confidence (bottom).

\subsection{Dredging and placement data}

The region had dredging data for 23 navigation channels and harbors within the DIS for both contract and USACE dredges. All dredging data in DIS were assumed to be O\&M (i.e., no New Work quantities). No placement data were available from DIS and were not included in the CRSB unless already incorporated within existing sediment budgets. Data for "Ambrose Channel Rock Pile" were not included in the CRSB because rocks are not littoral material. On average, the DIS data indicated that the USACE New York District (NAN) and USACE New England District (NAE) dredged 4.9 million $\mathrm{yd}^{3}$ of littoral sediment within this region (Table 3 ). The three harbors in Connecticut contributed 86,677 yd3/yr to the total. In Table 3 , 
"Total" is the total volume recorded in the DIS, "Total Days" indicates the number of days between the start date and end date of dredging, "Chan ID" is the unique 4-digit channel identification identifier, and "Annual Rate" is the average annual dredging volume for that channel.

Figure 16. CRSB for Region 3 showing composite exposure indices, cell gain/loss (upper) and cell confidence (lower); regions with both high exposure and erosion/low confidence are identified.

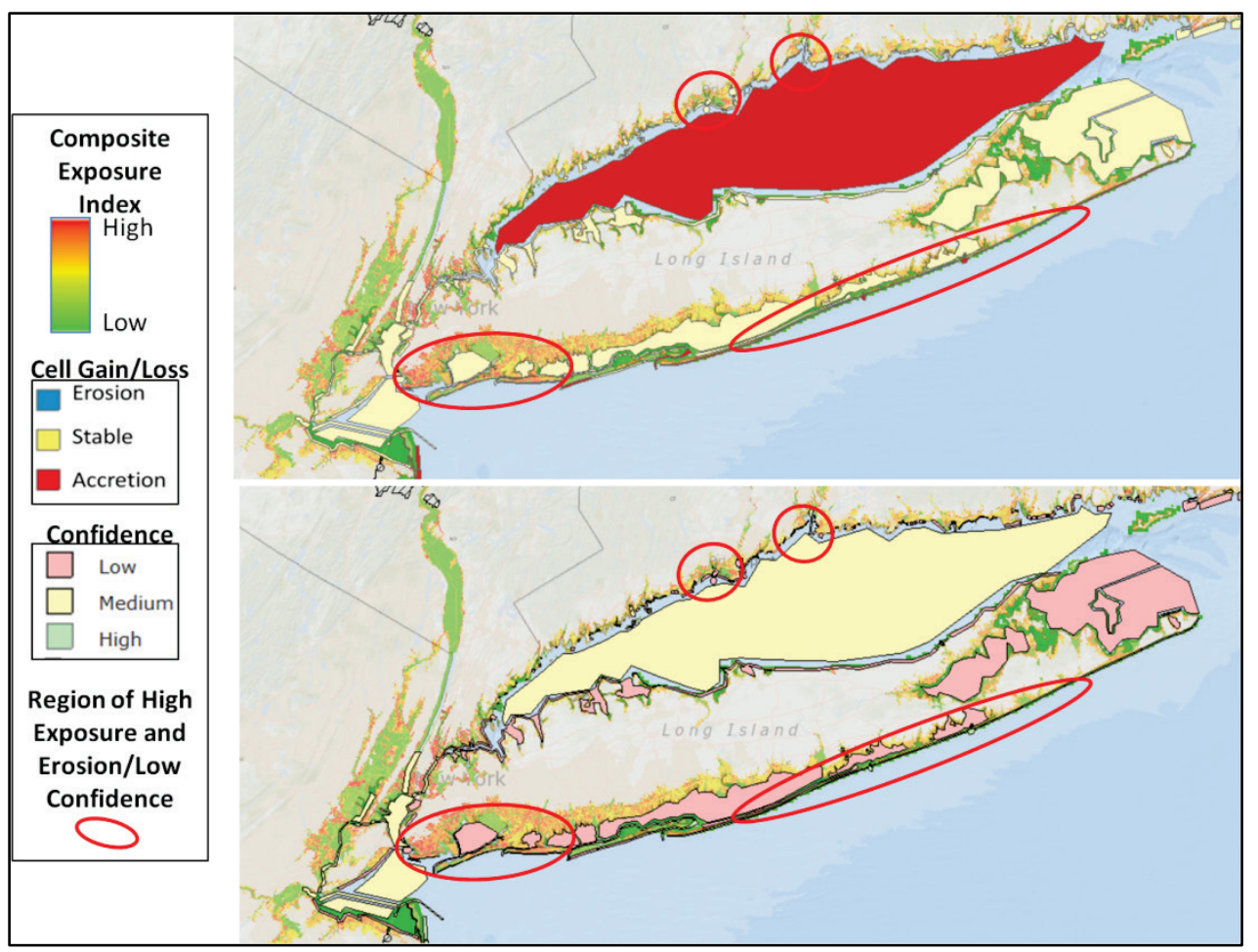

Table 3. DIS dredging data for Region 3 from 1990 to present (July 2013) for both contract and USACE dredges.

\begin{tabular}{|l|l|l|l|l|l|}
\hline \multicolumn{1}{|c|}{ Job Name } & \multicolumn{1}{|c|}{ Total, $\mathbf{y d}^{\mathbf{3}}$} & Total Days & \multicolumn{1}{c|}{ Chan ID } & \multicolumn{1}{|c|}{ Annual Rate, $\mathbf{y d}^{\mathbf{3}}$} & \multicolumn{1}{c|}{ Notes } \\
\hline $\begin{array}{l}\text { Ambrose Rock Pile, NY } \\
\text { Harbor }\end{array}$ & $3,624,000$ & 4,030 & 4903 & 328,228 & $\begin{array}{l}\text { Not littoral sediment; } \\
\text { not included in CRSB }\end{array}$ \\
\hline Buttermilk Channel, NY & 342,326 & 7,906 & 4902 & 15,804 & 3 records \\
\hline Clinton Harbor, CT & 70,790 & 4,611 & 2848 & 5,604 & NAE \\
\hline East River, NY & 469,650 & 5,173 & 3050 & 33,138 & 3 records \\
\hline East Rockaway Inlet, NY & $2,857,420$ & 7,778 & 2999 & 134,091 & \\
\hline Fire Island to Jones Inlet & $8,020,733$ & 4,901 & 3002 & 597,341 & \\
\hline $\begin{array}{l}\text { Flushing Bay and Creek, } \\
\text { NY }\end{array}$ & 126,759 & 4,002 & 3044 & 11,561 & 3 records \\
\hline Glen Cove Creek, NY & 74,220 & 3,646 & 3064 & 7,430 & 3 records \\
\hline Gowanus Bay, NY & 465,205 & 8,377 & 3046 & 20,270 & 3 records \\
\hline $\begin{array}{l}\text { Gravesend Bay } \\
\text { Anchorage, NY }\end{array}$ & 148,539 & 2,751 & 4910 & 19,708 & 3 records \\
\hline
\end{tabular}




\begin{tabular}{|l|l|l|l|l|l|}
\hline \multicolumn{1}{|c|}{ Job Name } & \multicolumn{1}{|c|}{ Total, $\mathbf{y d}^{3}$} & Total Days & \multicolumn{1}{c|}{ Chan ID } & Annual Rate, yd & \multicolumn{1}{|c|}{ Notes } \\
\hline $\begin{array}{l}\text { Hudson River Channel, } \\
\text { NY }\end{array}$ & $1,126,413$ & 1,952 & 3005 & 210,625 & \\
\hline Jamaica Bay, NY & $2,350,393$ & 7,913 & 3053 & 108,416 & \\
\hline Jones Inlet, NY & $1,644,673$ & 6,539 & 3040 & 91,804 & \\
\hline $\begin{array}{l}\text { Lake Montauk Harbor, } \\
\text { NY }\end{array}$ & 125,585 & 7,650 & 3010 & 5,992 & \\
\hline $\begin{array}{l}\text { Long Island Intracoastal, } \\
\text { NY }\end{array}$ & 290,875 & 7,072 & 3015 & 15,013 & \\
\hline New Haven Harbor, CT & 633,486 & 3,332 & 5198 & 69,394 & 3 records; NAE \\
\hline $\begin{array}{l}\text { New York Harbor-Sandy } \\
\text { Hook }\end{array}$ & 532,725 & 5,343 & 4906 & 36,392 & 3 records or fewer \\
\hline Newark Bay, NJ & 766,800 & 3,849 & 4588 & 72,716 & \\
\hline $\begin{array}{l}\text { NJ/NY Channels - Kill } \\
\text { Van Kull }\end{array}$ & $6,379,412$ & 5,144 & 4574 & 452,660 & \\
\hline $\begin{array}{l}\text { NY Hbr, KVK, Newark } \\
\text { Bay }\end{array}$ & $5,256,615$ & 889 & 3016 & $2,158,228$ & \\
\hline $\begin{array}{l}\text { NY\&NJ Channel-Arthur } \\
\text { Kill }\end{array}$ & $4,124,940$ & 5,668 & 4575 & 265,632 & \\
\hline Patchogue Harbor, CT & 23,230 & 726 & 2930 & 11,679 & NAE \\
\hline Port Jersey Channel & $4,079,500$ & 3,437 & 4905 & 433,232 & \\
\hline Raritan River, NJ & 703,785 & 6,247 & 3032 & 41,121 & \\
\hline Shinnecock Inlet, NY & $1,804,199$ & 7,110 & 3057 & 92,621 & \\
\hline Shrewsbury, NJ & 242,135 & 7,742 & 3033 & 11,416 \\
\hline Average Annual Rate for Region (without & Ambrose Rock Pile data) & & \\
\hline
\end{tabular}

The DIS dredging data lists several channels with only one dredging event, and as a result, it was not possible to compute an average annual shoaling rate at these sites. In order to provide as much detail as possible in this sediment budget, these channels and harbors are included as cells. The volumes dredged at each project are listed in Table 4. Since the total dredging volume is not in cubic yards per year, each volume was divided by 23 (number of years represented in the DIS database) to represent an average dredging volume per year from 1990 to 2013. Although these are not shoaling rates, the average dredging volume for this period was included as a representative removal value.

Channel locations were either adopted from the NCF or, because most channels for Region 3 are not yet available in the NCF, approximated based on online information. 
Table 4. DIS dredging data for Region 3 from 1990 to present (July 2013) for both contract and USACE dredges: data with 1-2 entries.

\begin{tabular}{|c|c|c|c|}
\hline Project & Total, $\mathrm{yd}^{3}$ & Year(s) & Channel ID \\
\hline Five Mile River, CT & 60,000 & 1999 & 2764 \\
\hline Norwalk, CT & 343,213 & 2006, 2008 & 5180 \\
\hline Housatonic River, CT & 63,825 & 2012 & 5206 \\
\hline Stony Creek Harbor, CT & 45,792 & 1995 & 2883 \\
\hline Guilford Harbor, CT & 10,425 & 1993 & 2575 \\
\hline Connecticut River, CT & 197,300 & 1991,1994 & 2978 \\
\hline North Cove, CT & 297,785 & 1991, 2009 & 2855 \\
\hline Pistol Point, CT & 63,800 & 2002 & 2960 \\
\hline
\end{tabular}

\subsection{Recommendations}

Of the 291 cells that have been created to characterize this region, 43 cells were not balanced (i.e., nonzero residuals), and 200 cells were created as placeholders and had no data. Note that these numbers misconstrue the proportion of Region 3 without information because placeholder cells were created with large spatial extent. Areas with good sediment budget coverage include the region mentioned previously, from Coney Island through Montauk Point, with the exception of the estuaries and bays. Studies to characterize sediment transport pathways and magnitudes for much of the south and north shores of Long Island Sound were not discovered.

Within Region 3, the following are recommended to improve understanding of sediment transport and, ultimately, regional sediment management practices:

- Update the characterization of sediment sources and sinks for the New York Bight area, which is a major metropolitan area with extensive dredging and placement and was greatly damaged by Hurricane Sandy. The source used in this study to represent the sediment budget for this area was from 1986 and may not reflect present-day processes. Many of the New York Bight sediment budgets were reported in units of metric tons per year. Gross assumptions were used for conversion in the CRSB. Those assumptions should be updated during a more rigorous analysis.

- Provide better characterization of sediment processes, dredging, and placement for the estuaries. Damage from Hurricane Sandy occurred 
on both the ocean and bay sides of barrier islands, and there may be improvements in sediment management that could be realized by comprehensive assessment of the estuaries behind narrow barrier islands, specifically Sandy Hook Estuary, Jamaica Bay, Great South Bay, Moriches Bay, Shinnecock Bay, and Gardiners Bay.

- Provide better characterization of regional sediment transport pathways and patterns for beaches along Long Island Sound. Although this area is less vulnerable to direct impact from hurricanes and northeasters, there are navigation channels and sediment management activities that could reduce future erosion of this area. 


\section{Region 4: Connecticut-Rhode Island Border through Maine ${ }^{1}$}

\subsection{Description of region}

Region 4 of the CRSB extends from the Connecticut-Rhode Island border through Maine and includes the coastal watersheds of Rhode Island, Massachusetts, New Hampshire, and Maine. This region includes NACCS planning regions RI1 and RI2, MA1 through MA5, and NH1 including the state of Maine to the Canadian border. General net sediment transport directions are shown in Figure 17.

Figure 17. General net sediment transport directions for Region 4, including NACCS planning regions RI1 and RI2, MA1 through MA5, NH1, and the state of Maine to the Canadian border.

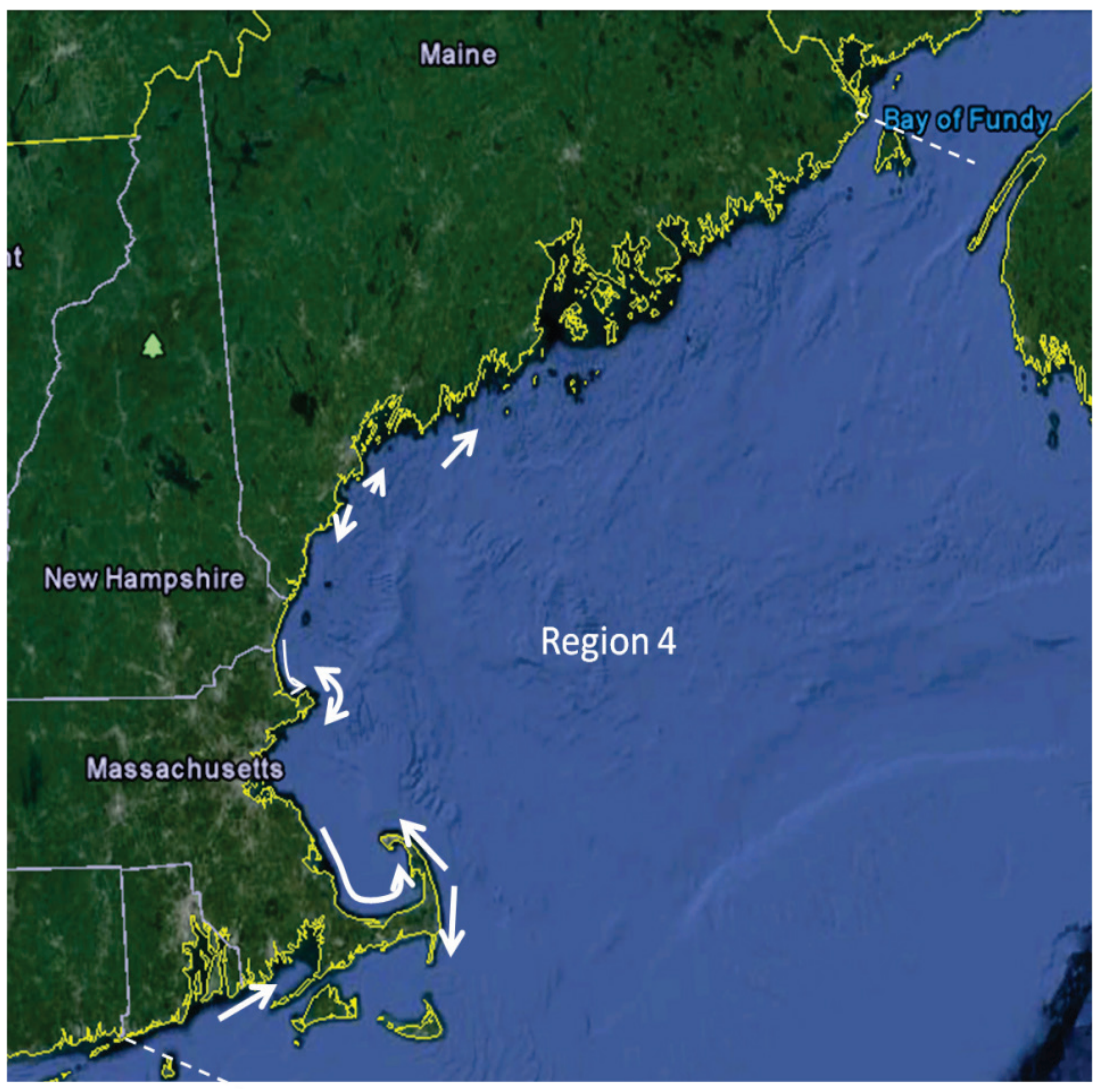

1 This chapter was written by Andrew Morang and Ashley Frey. 
New England is a complicated, paraglacial, geological terrain, with end moraine islands, drowned glacial valleys, sand spits, salt marshes, and bedrock outcrops. Paraglacial coasts are located in regions formerly covered by extensive glacial ice sheets and still retain extensive surface cover of easily erodible glaciogenic sediments (Hein et al. 2012). Some of the complex coastal morphologies found in this region include the following:

- barrier spits of southern Rhode Island, Cape Cod, Massachusetts Bay (south of Boston Harbor), and Plum Island

- glacial till bluffs of Block Island, Nantucket Island, Martha's Vineyard, and islands in Boston Harbor

- Narragansett Bay, a drowned glacial valley with a combination of bedrock outcrops, till bluffs, limited sand and gravel beaches, and limited salt marshes

- irregular and indented shorelines of Nantucket Sound and coastal Maine

- bedrock peninsulas with limited sandy beaches such as the Rockport Peninsula.

Unlike Regions 1-3, with Atlantic-facing beaches and barrier spits that extend for 10s or 100s of miles, New England's beaches are much shorter and usually bounded by a topographic feature such as a headland or channel. The south shore of Rhode Island west of Narragansett Bay has the closest resemblance to the Atlantic beach model of sandy beach/spit/pond complex. Figure 18 shows the sediment budget for the region, and details for the Cape Cod area are shown in Figure 19. Confidence levels for Region 4 are shown in Figure 20, in which low confidences indicate that no data were available for these cells.

The composite exposure index provided by NAD is shown for a portion of Region 4 in Figure 21, with areas having both high exposure indices and erosion/low confidence identified. NAD did not indicate exposure indices for the remainder of Region 4. Cells showing as stable (left) may not have data as indicated by low confidence (right). 
Figure 18. Region 4 CRSB from Rhode Island through Massachusetts; colors indicate erosion, accretion, or stability (no change) or no data in the cell (fluxes not shown for clarity).

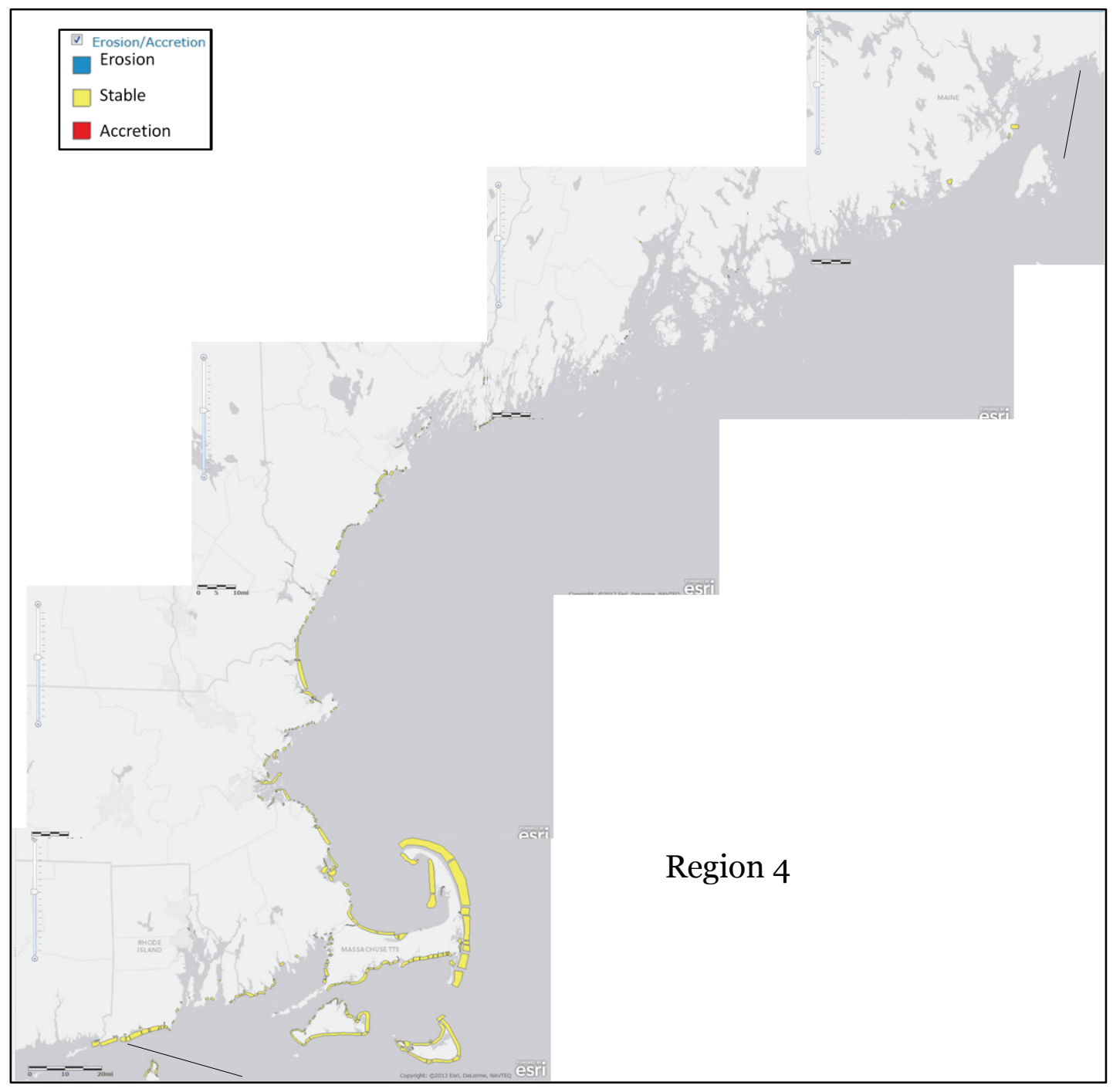

Figure 19. Detail of CRSB for Region 4: vicinity of Cape Cod, MA.

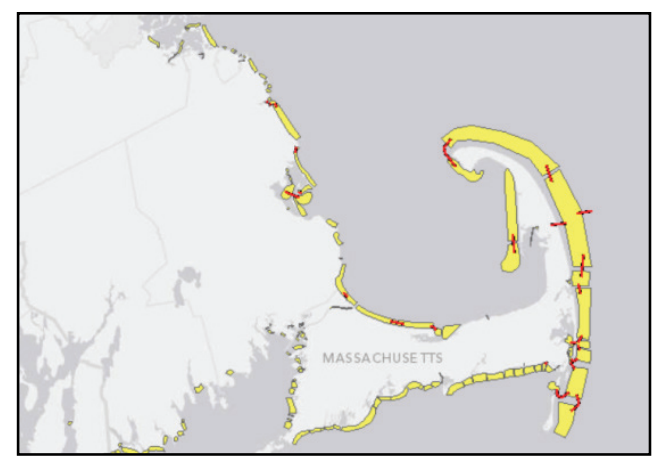


Figure 20. Region 4 CRSB showing confidence levels and coverage.

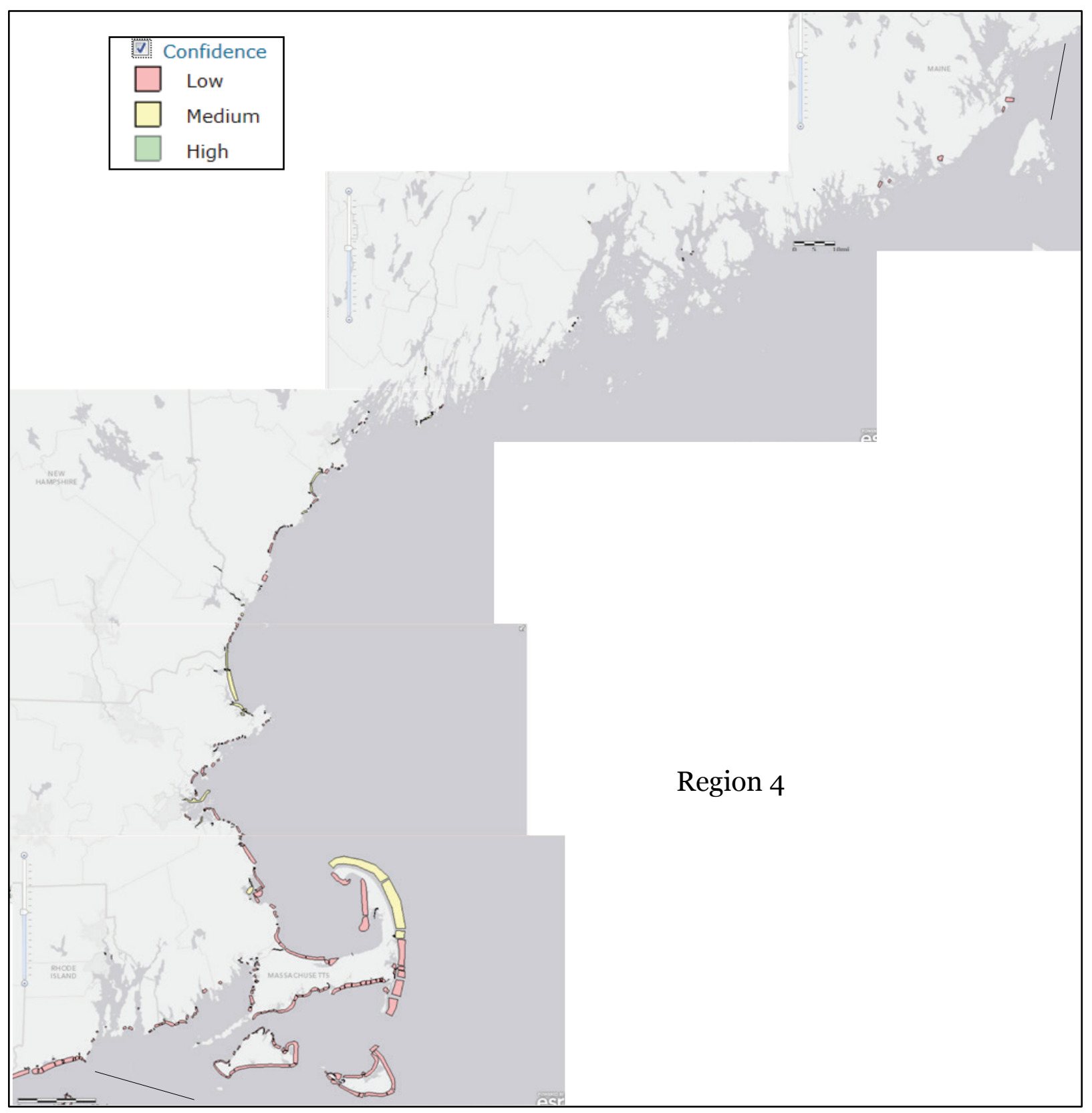


Figure 21. CRSB for Region 4 showing composite exposure indices, cell gain/loss (left) and cell confidence (right); regions with both high exposure and erosion/low confidence are identified.

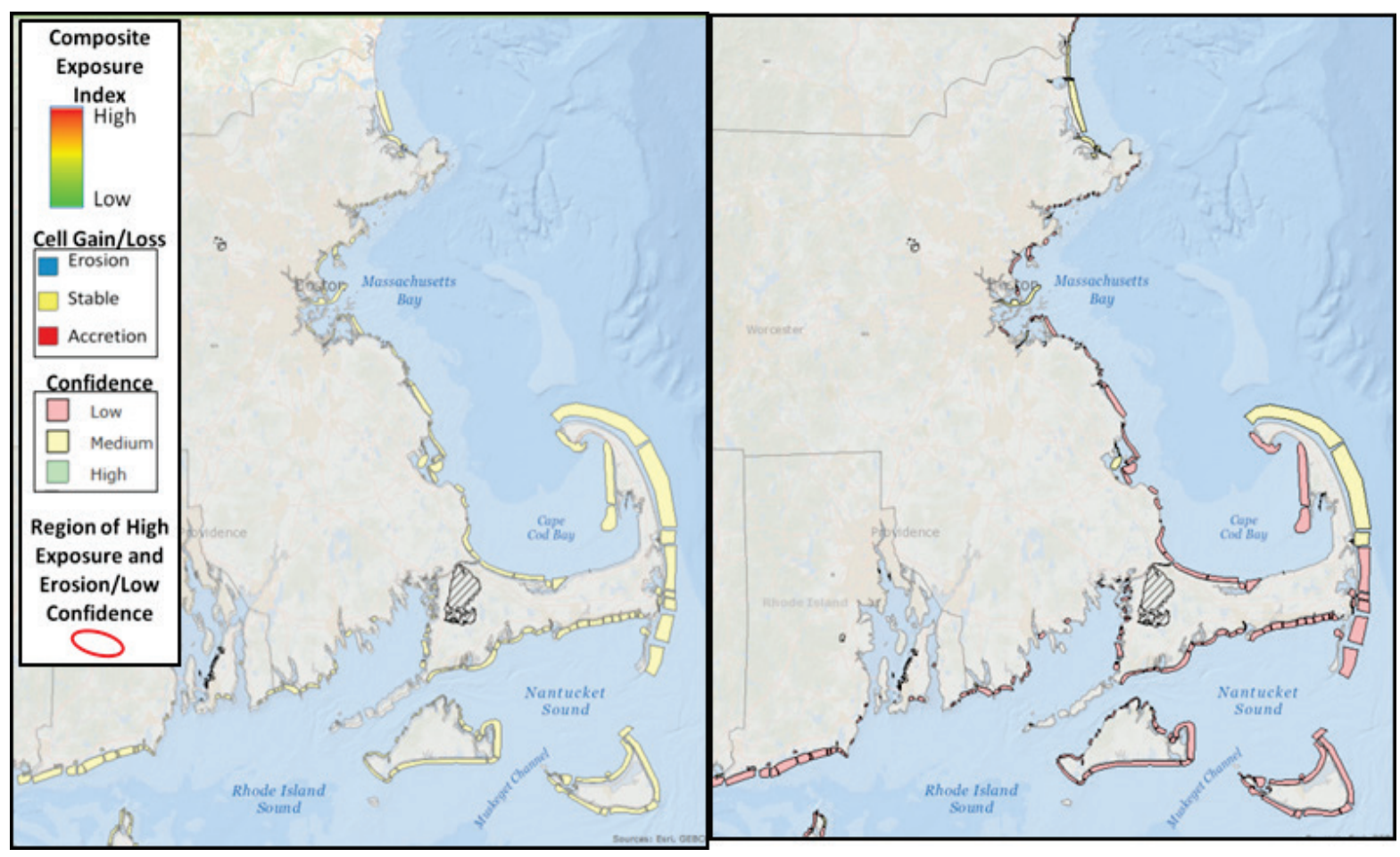

Many New England spits, such as the ones on the south shore of Martha's Vineyard or southern Cape Cod, are the result of sediment derived from nearby eroding till bluffs (Figure 22). In much of Massachusetts, New Hampshire, and Maine, spits and beaches are more limited and often consist of pocket beaches with bounding bedrock headlands (Figure 23). Because of the compartmentalized nature of the beach systems, the barriers typically average only 3,00o feet in length (Kelley 1987; Duffy et al. 1989). The source of sand in these pocket beaches is a combination of locally derived material and minor input from rivers (FitzGerald and van Heteren 1999). For this study, most of these pocket beaches have been treated as isolated cells because of the unknown fluxes. 
Figure 22. Sand spits on Cape Cod are fed by till bluffs at a rate of approximately $916,000 \mathrm{yd}^{3} / \mathrm{yr}$ (from Giese et al. (2011))

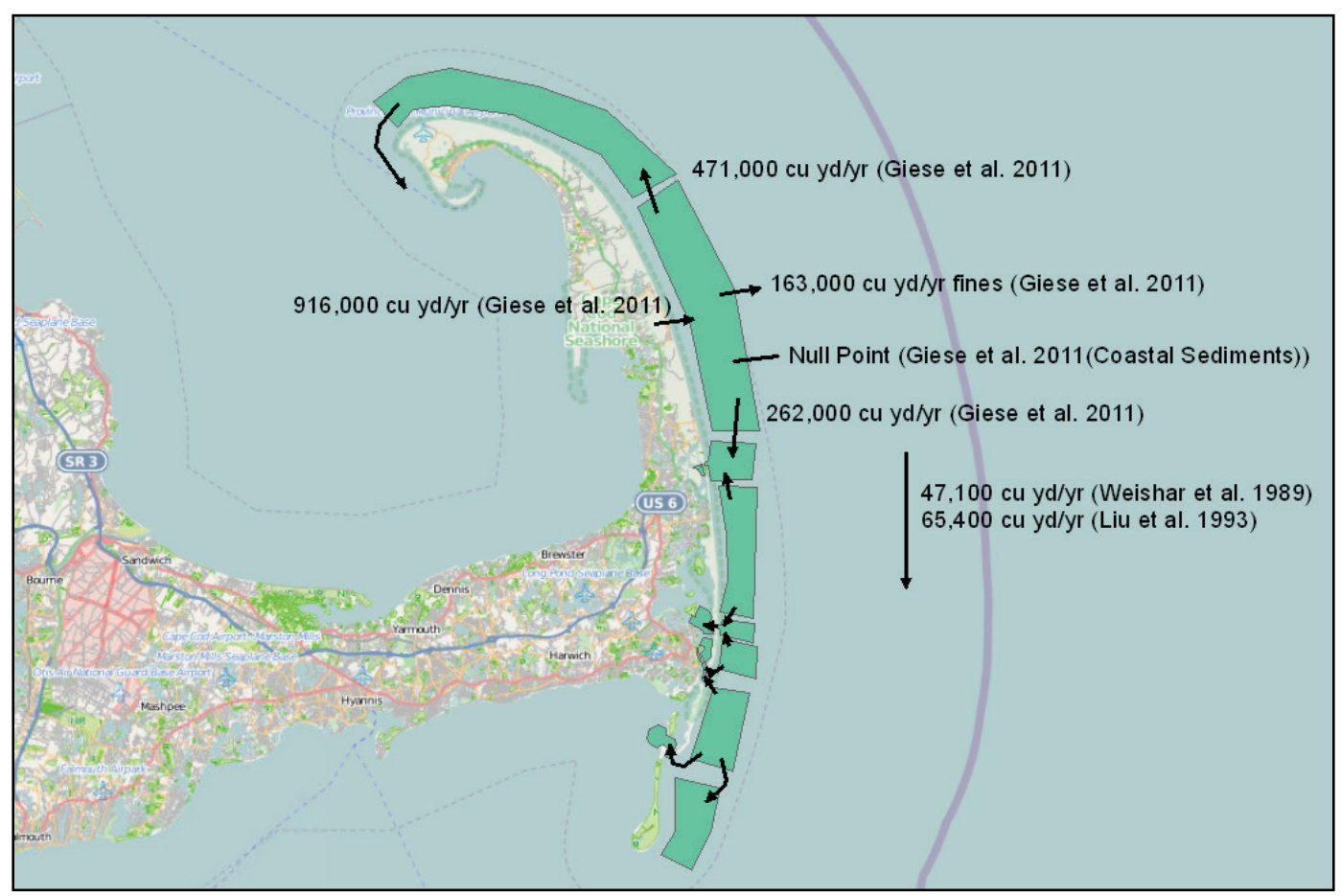

Figure 23. Rockport Peninsula, Massachusetts, showing isolated pocket beaches along the south shore and Essex River beach and shoal complex to the north. Essex River flux values in cubic yards per year from Smith and

FitzGerald (1994).

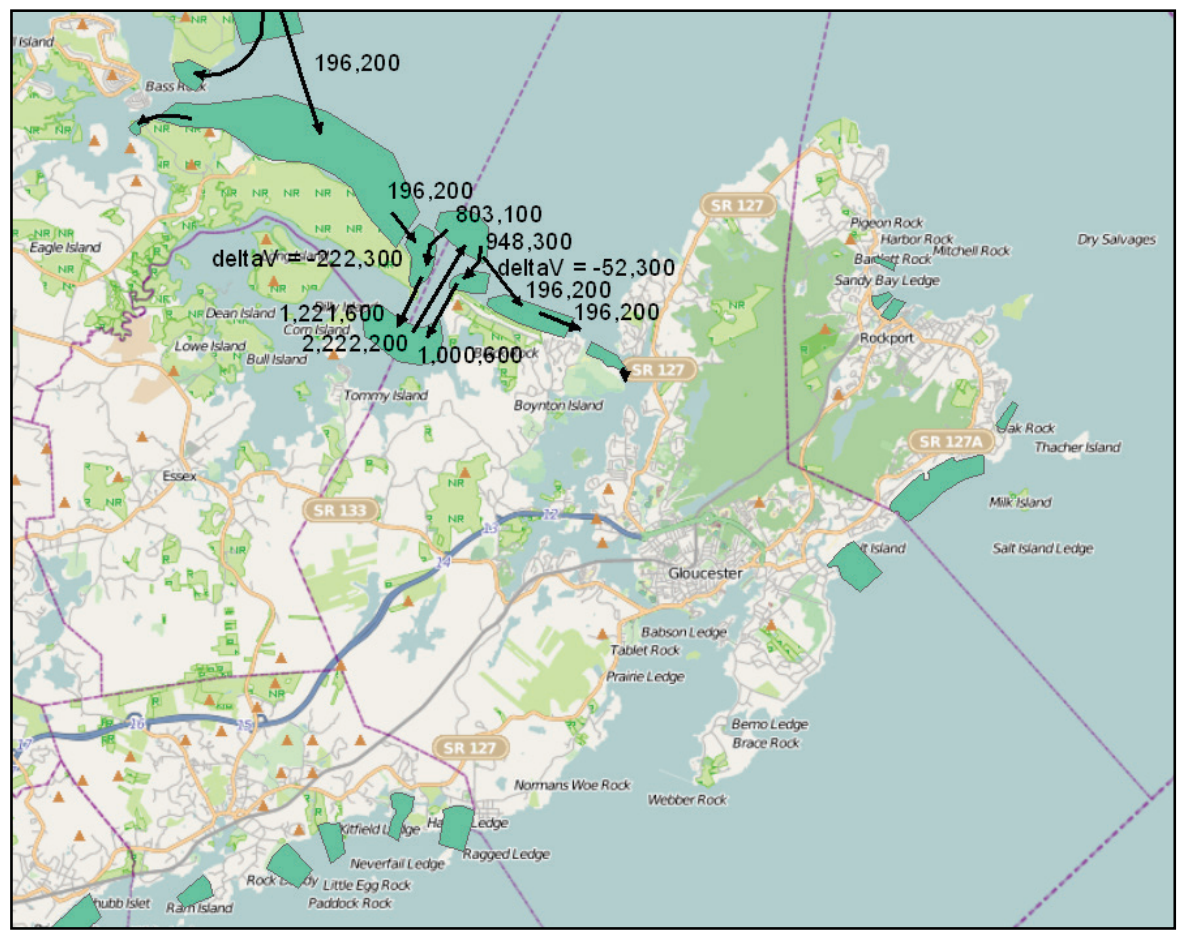


Northern New England is also different than the southern states in that this is the only area on the Atlantic seaboard where rivers bring sand directly to the open coast (FitzGerald et al. 2005). From New Jersey and southward, rivers draining the Appalachians carry fine-grained sediment into estuaries (Chesapeake and Delaware Bays) or into coastal ponds and marshes. Sediment on the North and Central Atlantic beaches is almost totally derived from recycled continental shelf deposits or man-made deposition. But in New England, the Connecticut, Androscoggin, Saco, Scarborough, Kennebec, Penobscot, and St. Croix Rivers (Passamaquaddy Bay) carry sand directly to the coast. At the mouth of the Kennebec River, Maine, the beaches at Popham Beach State Park are supplied by river-derived sand via complicated pathways (Figure 24). At Plum Island, MA, sediment data from the ebb shoal demonstrate the continued contribution of sediment to the barrier system from the Merrimack River (FitzGerald et al. 1994).

Figure 24. Mouth of the Kennebec River and beaches at Popham Beach State Park (flux pathways from Goldschmidt et al. (1991) and FitzGerald and Fink (1987)).

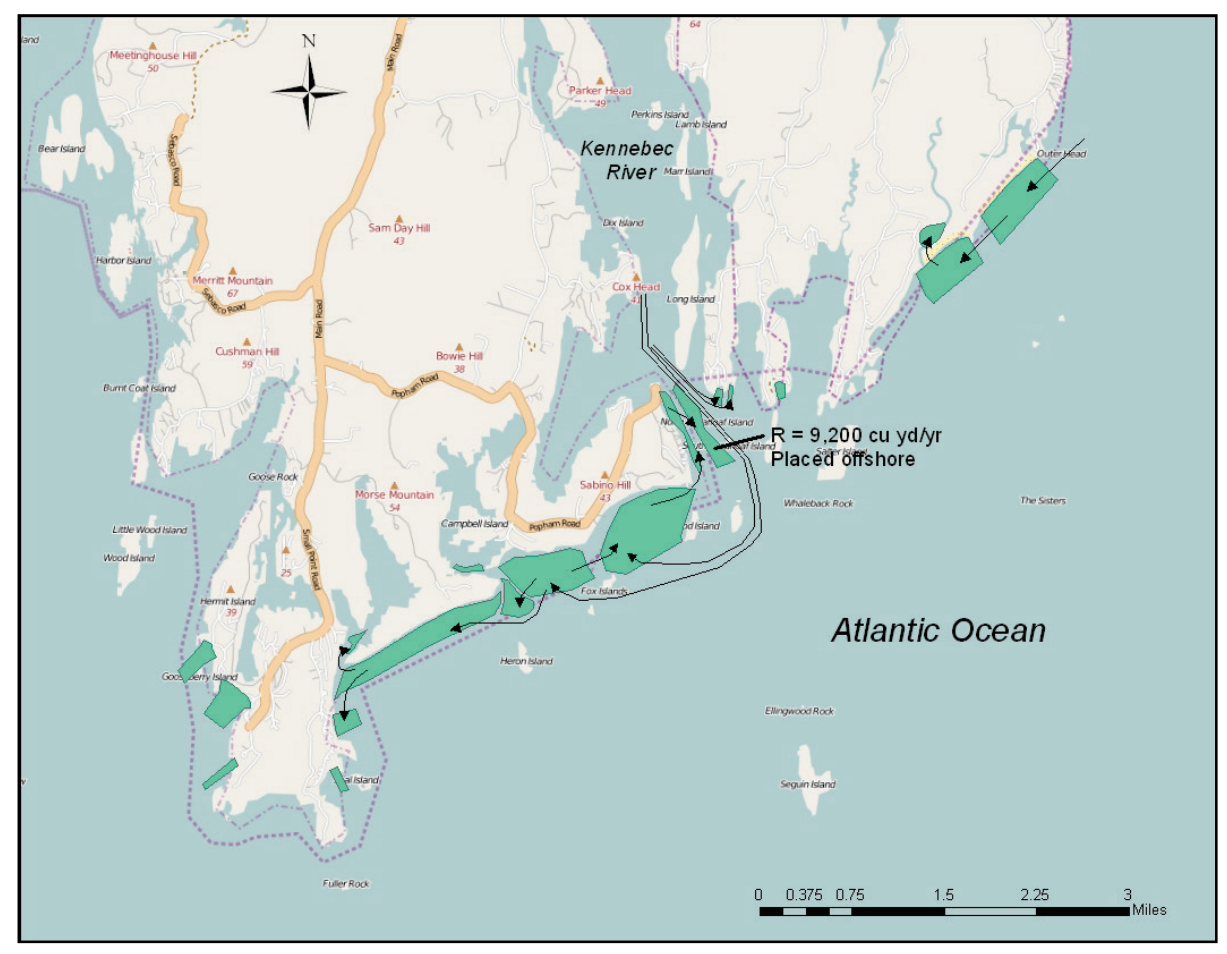

\subsection{Dredging and placement data}

New England contains a large number of Federal channels and harbors, many of which date back to the Colonial era. Most were active commercial harbors before the early twentieth century, shipping timber, manufactured goods, rock and gravel, ice, and textiles to markets around the world. In 
the post-World War II era, many of these harbors have changed emphasis to pleasure craft and, partly as a result, have not received regular dredging in recent decades.

Based on data from 1990 to July 2013, for sites with at least three dredging events, the DIS data indicated that 10 channels were dredged for an annual average of 193,000 $\mathrm{yd} 3 / \mathrm{yr}$ of littoral sediment within this region (Table 5). In Table 5, "Total" is the total volume recorded in the DIS, "Total Days" indicates the number of days between the start date and end date of dredging, "Chan ID" is the unique 4-digit channel identification identifier, and "Annual Rate" is the average annual dredging volume for that channel.

Table 5. DIS dredging data for Region 4 from 1990 to present (July 2013) for both contract and USACE dredges.

\begin{tabular}{|l|l|l|l|l|}
\hline \multicolumn{1}{|c|}{ Project } & \multicolumn{1}{|c|}{ Total, yd ${ }^{3}$} & Total Days & \multicolumn{1}{c|}{ Channel ID } & \multicolumn{1}{c|}{ Annual Rate, yd3 } \\
\hline Andrews River, Harwich, MA & 58,805 & 4,361 & 2932 & 4,922 \\
\hline Aunt Lydias Cove, Chatham, MA & 378,850 & 6,002 & 2950 & 23,039 \\
\hline Block Is Harbor of Refuge-Emergency & 258,165 & 7,470 & 2731 & 12,614 \\
\hline Cuttyhunk Harbor, MA & 44,055 & 7,674 & 2672 & 2,095 \\
\hline Green Harbor, Marshfield, MA & 726,334 & 8,371 & 2769 & 31,670 \\
\hline Kennebec River, ME * & 367,812 & 7,274 & 2783 & 18,456 \\
\hline Newburyport Harbor, MA & 380,426 & 2,249 & 2840 & 61,741 \\
\hline Sesuit, Dennis, MA & 183,525 & 6,259 & 2776 & 10,702 \\
\hline Stage Harbor, Chatham, MA & 325,820 & 6,892 & 2838 & 17,255 \\
\hline Wells Harbor, ME & 225,028 & 7,987 & 2841 & 10,284 \\
\hline \multicolumn{2}{|c|}{ Average Annual Rate for Region } & $192,778 \mathrm{cu}$ yd/ year \\
\hline
\end{tabular}

*Two regions were dredged, Bath and the river mouth; for the sediment budget, it was assumed 50\% or 9,200 $\mathrm{yd}^{3} / \mathrm{yr}$ was dredged from each site.

The DIS dredging data lists many channels with only one dredging event, and as a result, it was not possible to compute an average annual shoaling rate at these sites. In order to provide as much detail as possible in this sediment budget, these channels and harbors are included as cells. The volumes dredged at each project are listed in Table 6 . Because the total dredging volume is not in cubic yards per year, each volume was divided by 23 (number of years represented in the DIS database) to represent an average dredging volume per year from 1990 to 2013. Although these are not shoaling rates, the average dredging volume for these sites was used to represent removal. 
Table 6. DIS dredging data for Region 4 from 1990 to present (July 2013) for both contract and USACE dredges: data with 1-3 entries.

\begin{tabular}{|c|c|c|c|}
\hline Project & Total, $\mathrm{yd}^{3}$ & Year(s) & Channel ID \\
\hline Belfast Harbor, ME & 35,000 & 2003 & 2834 \\
\hline Boston, MA & $4,700,000$ & 2000 & 2750 \\
\hline Bullocks Cove, RI & 54,350 & 1995,2010 & 2729 \\
\hline Cape Cod Canal, MA & 137,173 & 2002,2010 & 2752 \\
\hline Cocheco River, NH & 40,200 & $\begin{array}{l}2004,2006 \\
2010\end{array}$ & \\
\hline Cohasset Harbor, MA & 107,852 & 2000 & 2755 \\
\hline Great Salt Pond, RI & 56,695 & 2012,2013 & 2952 \\
\hline Hampton Harbor, $\mathrm{NH}$ & 50,000 & 2012 & 2845 \\
\hline Hingham Harbor, MA & 226,000 & 1997,2011 & \\
\hline Hyannis Harbor, MA & 30,000 & 2013 & 2679 \\
\hline Kennebunkport, ME & 7,760 & 2004 & 2784 \\
\hline Little Harbor, NH & 37,000 & 2001 & 2719 \\
\hline Little Narragansett Bay, RI & 47,000 & 1996 & 5218 \\
\hline Narraguagus River, ME & 76,841 & 2007 & 2645 \\
\hline Oak Bluffs, MA & 8,275 & 2012 & 5409 \\
\hline Pawtuxet Cove, RI & 105,020 & 2006, 2011 & 2735 \\
\hline Perkins Cove, ME & 22,100 & 1993 & 2844 \\
\hline Plymouth Harbor, MA & 200,000 & 2011 & \\
\hline Point Judith, RI & 23,980 & 2010 & 2847 \\
\hline Portsmouth Harbor, NH & 77,000 & 1991 & 2720 \\
\hline Royal River, ME & 100,000 & 1997 & 2815 \\
\hline Salem Harbor, MA & 161,926 & 2000 & 2693 \\
\hline Saugus River, MA & 89,675 & 2001 & 4665 \\
\hline Sciuate Harbor, MA & 280,000 & 2003 & 2846 \\
\hline Seabrook Harbor, NH & 115,000 & 2012 & 2845 \\
\hline Union River, ME & 74,957 & 2001, 2003 & 2662 \\
\hline Westport Harbor, MA & 32,000 & 2007,2009 & \\
\hline Weymouth Fore River, MA & 312,000 & 2007 & 2936 \\
\hline York Harbor, ME & 47,704 & 1996 & 2857 \\
\hline
\end{tabular}

Table 7 lists dredging or beach placements based on various data sources other than the DIS. Cells dredging and placement rates were included in the CRSB for these channels, harbors, and beaches. 
Table 7. Dredging and placement volumes for Region 4 from sources other than DIS.

\begin{tabular}{|l|l|l|l|}
\hline \multicolumn{1}{|c|}{ Project } & \multicolumn{1}{|c|}{ Total, $\mathbf{y d}^{\mathbf{3}}$} & Total years & ${\text { Annual Rate, } \mathbf{y d}^{\mathbf{3}}}$ \\
\hline $\begin{array}{l}\text { Duxbury Harbor, MA (from NAE PowerPoint presentation and } \\
\text { The Duxbury Reporter) }\end{array}$ & 306,000 & 36 & 8,510 \\
\hline Saco River, ME (Kelley et al. 2005) & 545,500 & 66 & 8,300 \\
\hline Scarborough River, ME & 95,000 & 21 & 4,500 \\
\hline Placement on Western Beach at Prouts Neck, Scarborough, ME & 82,000 & 7 & 11,700 \\
\hline Piscataqua River, ME-NH & 14,000 & 13 & 1,100 \\
\hline Portland Harbor, ME (from NAE PowerPoint presentation) & 600,000 & 12 & 50,000 \\
\hline Merrimack River Entrance (Hein et al. 2012) & $3,400,000$ & 62 & 54,000 \\
\hline
\end{tabular}

\subsection{Recommendations}

Of the 388 cells that have been created to characterize this region, 59 cells were not balanced (i.e., nonzero residuals), and 322 cells were created as placeholders and had no data. Within Region 4, the following are recommended to improve understanding of sediment transport and, ultimately, regional sediment management practices:

- Develop an understanding of sediment pathways from rivers and the nearshore, to pocket beaches of Maine and Massachusetts. These isolated sandy beaches receive sand from the rivers and/or offshore, but the pathways of delivery and the forcing are not known.

- Analyze historical data for the next phase of the sediment budget. For Rhode Island and possibly other locations, beach profile data exist from the 1960s, and there have been recent regional measurements of forcing conditions for use in calculating potential transport.

- Develop a long-term database of historical dredging and placement data. Because many navigation channels in Region 4 are not presently maintained, data to quantify the gross transport and riverine input into the channels do not exist in the DIS. By analyzing historical records, valuable information about these quantities can be gleaned for the next phase of the sediment budget. 


\section{Summary and Recommendations}

Preparation of the conceptual regional sediment budget (CRSB) provided an opportunity to review literature and existing studies documenting geologic and engineering aspects of sediment transport and sedimentation for the coastal watersheds within the Norfolk, Baltimore, Philadelphia, New York, and New England Districts. If existing information was not available, general pathways of sediment transport that could be observed from aerial photography or other sources were entered into the CRSB. The CRSB as prepared provides a snapshot of knowledge of sediment transport and engineering activities within this region.

It is noted that the temporal scales of individual budgets included in the CRSB extend from engineering scales ranging from years to decades, to geologic-scales up to thousands of years. Thus, the source of data and associated time scale must be considered when reviewing the CRSB. For many locations, shorelines have been recently armored (i.e., in the past $30+$ years), which will not be captured in the geologic-scale information.

Figure 25 shows an overall view of the CRSB with composite exposure indices and locations of high or medium confidence in the sediment budget. All other locations had minimal knowledge of sediment transport, conflicts in sediment budgets, or no data. For more detail, please see detailed figures of confidence levels shown in previous chapters. With the exception of portions of Chesapeake Bay and Long Island Sound, the knowledge indicated in Figure 25 does not extend to the bays and estuaries. Overall, 990 cells were created in the CRSB, and 660 cells, or $67 \%$, were created as placeholders and did not have data with which to populate the budget.

Recommendations for revising the CRSB and developing the next generation sediment budget include the following:

- Review the CRSB with District and local experts and update information. There may be databases and knowledge that were not discovered in preparation of the CRSB that should be included in an updated version. 
- Input all navigation channels within the NCF. Knowledge of the footprint for the navigation channels will provide more accurate characterization of the sediment budget.

- Add placement information and quality of sediment (e.g., sand, fines) to the DIS which then can be incorporated into the CRSB. Sediment dredged from the navigation channels is a valuable resource for placement on adjacent beaches, building wetlands in the backbay, creating habitat, etc. Knowledge of the sediment quality, volume, and present practices would provide information with which to inform management decisions.

- Resolve conflicts in fluxes, volume change, dredging, and placement. If two adjacent sediment budgets had differing values for fluxes connecting these two cells, this conflict was not resolved in the CRSB but rather carried through for other experts to resolve.

- Develop a historical database on dredging and placement for all navigation channels in the northeast Atlantic. A historical dredging database will provide information on gross transport rates and river input to the region, which will be a valuable data set for development of the next generation of the sediment budget. The database will be especially valuable for Region 4 in which many channels are not routinely maintained.

- Develop a future sediment budget that builds upon the CRSB and considers how climate change (e.g., precipitation and storms) and relative sea level change could modify the budget. 
Figure 25. Overall summary of CRSB showing locations that had good-quality sediment budget data.

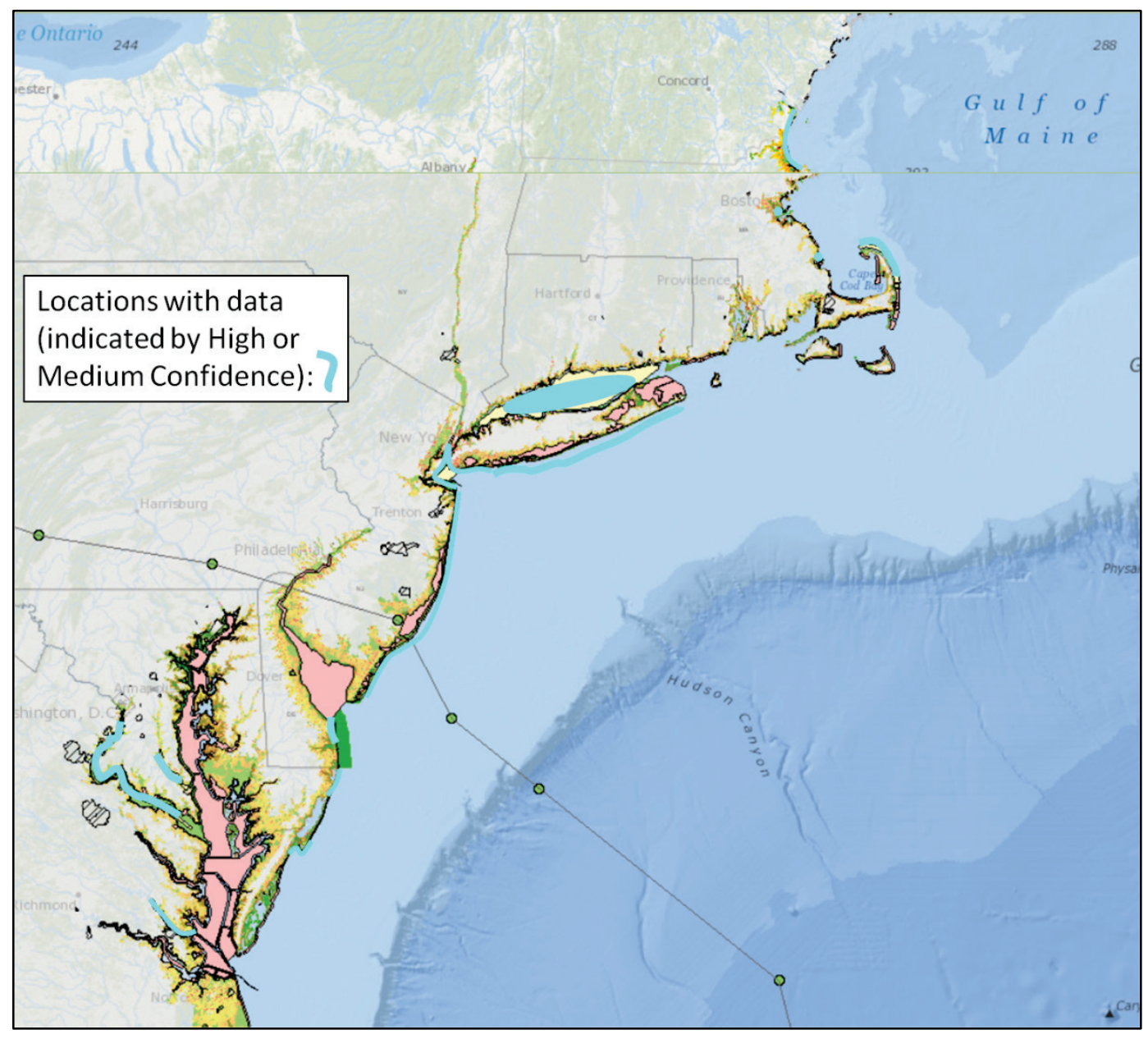




\section{References}

Batten, B. K., and N. C. Kraus. 2006. Evaluation of shore erosion downdrift of Mattituck Inlet, New York: Section 111 study. ERDC/CHL TR-06-1.Vicksburg, MS: U.S. Army Engineer Research and Development Center.

Bokuniewicz, H. J., and J. M. Ellsworth. 1986. Sediment budget for the Hudson system. Northeastern Geology 8(3): 156-164.

Bowen, A. J., and D. L. Inman. 1966. Budget of littoral sand in the vicinity of Point Arguello, California. Technical Memorandum No. 19. Ft. Belvoir, VA: U.S. Army Coastal Engineering Research Center.

Briggs, M. J., and E. F. Thompson. 2008. Wave climate and littoral sediment transport study for Virginia Beach, VA-Rudee Inlet to Cape Henry: Hydraulic model study. ERDC/CHL TR-08-15. Vicksburg, MS: U.S. Army Engineer Research and Development Center.

Byrnes, M.R. 2008. Coastal assessment report: Beach Changes adjacent to the Montauk Harbor Jetties, New York, with special reference to the Cole Property at 112 Soundview Drive. Prepared for Mr. Manning Cole. Mashpee, MA: Applied Coastal Research and Engineering, Inc.

Caldwell, J. M. 1966. Coastal processes and beach erosion. Journal of the Society of Civil Engineers 53(2): 142-157.

Dolan, T. J., P. G. Castens, C. J. Sonu, and A. K. Egense. 1987. Review of sediment budget methodology: Oceanside littoral cell, California. Proceedings, Coastal Sediments '87 ASCE 2: 1289-1304.

Duffy, W., D. F. Belknap, J. T. Kelley. 1989. Morphology and stratigraphy of small barrier-lagoon systems in Maine. Marine Geology 88: 243-262.

FitzGerald, D. M., and L. K. Fink. 1987. Sediment dynamics along an indented coast: Popham Beach-Kennebec River Maine. IN: Coastal Sediments 1987, ed. N. C. Kraus, Proceedings of a Specialty Conference on Advances in Understanding of Coastal Sediment Processes, New Orleans, LA, May 12-14, 1987, Vol. II: 20472061.

FitzGerald, D. M., P. S. Rosen, S. van Heteren. 1994. New England barriers. In Geology of Holocene Barrier Island Systems, ed. R. A. Davis, 305-394. Berlin: SpringerVerlag.

FitzGerald, D. M., and S. van Heteren. 1999. Classification of paraglacial barrier systems: Coastal New England, USA. Sedimentology 46: 1083-1108. 
FitzGerald, D., I. V. Buynevich, M. S. Fenster, J. T. Kelley, and D. F. Belknap. 2005. Coarse-grained sediment transport in Northern New England Estuaries: A synthesis. In High Resolution Morphodynamics and Sedimentary Evolution of Estuaries, Coastal Systems and Continental Margins, Vol. 8, Ch. 10, ed. D. M. FitzGerald and J. Knight, 195-213. (http://link.springer.com/content/pdf/10.1007\%2F1-4020-3296-X_10.pdf , accessed June 26, 2013).

Giese, G. S., M. B. Adams, S. S. Rogers, S. L. Dingman, M. Dingman, and T. L. Smith. 2011. Coastal sediment transport on outer Cape Cod, Massachusetts: Observation and theory. In The Proceedings of the Coastal Sediments 2011. Miami, FL: World Scientific, 2353-2365.

Goldschmidt, P. M., D. M. FitzGerald, and L. K. Fink, Jr. 1991. Processes affecting shoreline changes at Morse River inlet, central Maine coast. Shore \& Beach 59(2): $33-40$.

Gravens, M. B., N. W. Scheffner, L. W. Chou, L. S. Lillycrop. 1991. Coastal processes at Coney Island New York. Prepared for U.S. Army Engineer District, New York.

Hapke, C. J., E. A. Himmelstoss, M. Kratzmann, J. H. List, and E. R. Thieler. 2010. National assessment of shoreline change; historical shoreline change along the New England and Mid-Atlantic coasts. U.S. Geological Survey Open-File Report 2010-1118. http://pubs.usgs.gov/of/2010/1118/

Hein, C. J., D. M. FitzGerald, E. A. Carruthers, B. D. Stone, W. A. Barnhardt, and A. M. Gontz. 2012. Refining the model of barrier island formation along a paraglacial coast in the Gulf of Maine. Marine Geology 307-310: 40-57.

Herman, J., and C. Friedrichs. 2010. Estuarine suspended sediment loads and sediment budgets in tributaries of Chesapeake Bay: Phase 1: York, Patuxent, and Potomac Rivers. Special Report in Applied Marine Science and Ocean Engineering, No. 420. Gloucester Point, VA: Virginia Institute of Marine Science.

Herman, J. D. 2012. Estuarine sediment budgets for Chesapeake Bay tributaries. ERDC/CHL CHETN-XIV-23. Vicksburg, MS: U.S. Army Engineer Research and Development Center.

Hobbs, C. H., J. P. Halka, R. T. Kerhin, and M. J. Carron. 1990. A 100-year sediment budget for Chesapeake Bay. Special Report in Applied Marine Science and Ocean Engineering, No. 307. Gloucester Point, VA: Virginia Institute of Marine Science.

Hobbs, C. H., J. P. Halka, R. T. Kerhin, and M. J. Carron. 1992. Chesapeake Bay sediment budget. Journal of Coastal Research 8(2): 292-300.

Kana, T., and F. Stevens. 1992. Coastal geomorphology and sand budgets applied to beach nourishment. In Proceedings Coastal Engineering Practice '92, ASCE, 29-44.

Kelley, J. T. 1987. Sedimentary environments along Maine's estuarine coastline. In Glaciated Coasts, ed. D. M. FitzGerald and P. S. Rosen, 151-176. San Diego: Academic Press. 
Kelley, J. T., D. C. Berber, D. F. Belknap, D. M. FitzGerald, S. van Herten, and S. M. Dickson. 2005. Sand budgets at geological, historical and contemporary time scales for a developed beach system, Saco Bay, Maine, USA. Marine Geology 14: 117-142.

King, D. B., D. L. Ward, M. H. Hudgins, and G. G. Williams. 2011. Storm damage reduction project design for Wallops Island, Virginia. ERDC/CHL TR-11-9. Vicksburg, MS: U.S. Army Engineer Research and Development Center.

Lewis, R. S., and M. DiGiacomo-Cohen, M. 2000. A review of the geologic framework of the Long Island Sound Basin, with some observations relating to post glacial sedimentation. Journal of Coastal Research 16(3): 522-532.

Morang, A., G. G. Williams, and J. W. Swean. 2006. Beach erosion mitigation and sediment management alternatives at Wallops Island, VA. CHL/ERDC TR-o621. Vicksburg, MS: U.S. Army Engineer Research and Development Center.

Offshore \& Coastal Technologies, Inc. 2011. Geomorphic and sediment budget analysis of Fenwick and Assateague Islands, Maryland. Prepared for U.S. Army Corps of Engineers, Baltimore District. Chadds Ford: Offshore \& Coastal Technologies, Inc.

Offshore \& Coastal Technologies, Inc., East Coast. 2010. Mt. Sinai Harbor, NY, hydrodynamic modeling and sediment budget analysis in support of evaluation of management alternatives. Prepared for U.S. Army Corps of Engineers, New York District. Chadds Ford, PA: Offshore \& Coastal Technologies, Inc., East Coast.

Rosati, J. D. 2005. Concepts in sediment budgets. Journal of Coastal Research 21(2): 307-322.

Silveira, T. M., and N. P. Psuty. 2009. Morphological responses of adjacent shoreline segments on a fetch-restricted estuarine beach. Proceedings of the 1oth International Coastal Symposium ICS 2009. Journal of Coastal Research Special Issue 56 (1): 208-212.

Smith, J. B., and D. M. FitzGerald. 1994. Sediment transport patterns at the Essex River Inlet ebb-tidal delta, Massachusetts, U.S.A. Journal of Coastal Research 10(3): 752-774.

URS Group and Moffatt \& Nichol Joint Venture. 2010. The Long Island coastal planning project, inventories of sediment budgets and borrow areas, and borrow area management plans. Prepared for U.S. Army Corps of Engineers, New York District.

U.S. Army Corps of Engineers (USACE), Institute for Water Resources. 2015. Dredging information system. http://www.navigationdatacenter.us/dredge/dredge.htm, last updated 20 January 2015, accessed 22 January 2015.

U.S. Army Corps of Engineers (USACE), New York District. 1988. Monitoring program, final report for East Rockaway Inlet and Jamaica Bay, New York. U.S. Army Corps of Engineers, New York District. 
- 1989. Reconnaissance report, Atlantic Coast of Long Island, Jones Inlet to East Rockaway Inlet, Long Beach Island, New York. U.S. Army Corps of Engineers, New York District.

- 2004. Sediment transport analysis, Village of Asharoken, New York. North Shore of Long Island, New York Combined Erosion Control and Storm Damage Protection Feasibility Study, Final Report, August. U.S. Army Corps of Engineers, New York District.

- 2006. The Atlantic Coast of New Jersey regional sediment budget 1986-2003: Manasquan Inlet to Sea Bright. U.S. Army Corps of Engineers, New York District.

USACE, Norfolk District. 2006. Environmental assessment: Virginia Beach hurricane protection project. U.S. Army Corps of Engineers, Norfolk District.

USACE, Philadelphia District. 1996. Rehoboth Beach/Dewey Beach final feasibility report and environmental impact statement (EIS). U.S. Army Corps of Engineers, Philadelphia District.

- 2006. The Atlantic Coast of New Jersey regional sediment budget 1986-2003: Cape May Point to Manasquan Inlet. U.S. Army Corps of Engineers, Philadelphia District.

U.S. Geological Survey (USGS). 2003. A summary report of sediment processes in Chesapeake Bay and watershed. Water Resources Investigation Report 03-4123. Washington, DC: U.S. Dept. of the Interior, U.S. Geological Survey.

Van Gaalen, J. F. 2004. Longshore sediment transport from northern Maine to Tampa Bay, Florida: A comparison of longshore field studies to relative potential sediment transport rates derived from wave information study hindcast data. M.S. Thesis, University of South Florida, Tampa.

Virginia Institute of Marine Science (VIMS). 2013. Chesapeake Bay shoreline evolution reports. http://web.vims.edu/physical/research/shoreline/Publications-Evolution.htm. Accessed 7/15/2013. 


\section{Appendix A: Shoaling Calculations ${ }^{1}$}

\section{A.1 Method}

To determine the shoaling rate of the USACE channels in NAD, the most complete and immediately available data are in the DIS ${ }^{2}$ database, which includes both contracted and in-house USACE dredging projects. All dredging and beach project management records in the DIS database from 1990 to the time of this study (July 2013) were obtained from the DIS point of contact and used in the analyses.

\section{A.2 National Channel Framework}

The dredging records in the DIS for NAD were manually referenced to the channel framework "REF_ALL_PROJ_ID" which is a unique, four-digit number for each channel segment. When these project subsections are a portion of a larger project, the four-digit number in the column "XREF_ALL_PROJ_ID" connects the channel segments to the larger project. Connecting the DIS spreadsheets to the channel framework's unique four-digit number for each channel portion allows for interconnectivity between the channel framework and the dredging records and thus provides for geo-referencing.

\section{A.3 Shoaling rate estimate}

A spreadsheet containing the DIS data since 1990 for all of NAD was obtained from the DIS point of contact and a Channel Framework ID was assigned for each project record for both contracted and in-house projects. A Matlab code was written to calculate annual shoaling rate estimates for each project, using the Channel Framework ID and the criteria that at least three dredging events exist for the calculation.

Similar columns between both the contracted and in-house DIS records were used to combine them into a single spreadsheet for the purposes of obtaining the most accurate and complete list of shoaling averages. The

\footnotetext{
1 This appendix was written by Coraggio Maglio and Robert C. Thomas.

${ }^{2}$ Dredge Information System (DIS), https://dis.usace.army.mil/pls/ndis/f?p=103:1:1425082365550032. For more information about DIS, please contact: CEIWR-NDC.DIS@usace.army.mil.
} 
condensed DIS spreadsheet had to be cleaned of any blank data in the fields of interest, or that record would be skipped by the Matlab script. The DIS records do not have all of the necessary fields filled out to properly run such a script; other fields were thus used to populate the missing information. For example, the "ESTEND" column, which stands for the end date of actual work being conducted, had blank fields filled with the fiscal year data column. For this study, it was specified for the purposes of being conservative that the end date was 1 January of that fiscal year since most of these missing fields were from the early 1990s. An if-then statement was used to supplement any missing fields in the "ACTUALCY" column by inserting the data from the "EQ_CU_YD" column. Similarly, an if-then statement was used to supplement missing data in the "ACTUAL_CST" column by inserting the data from the "TOT_BID" column.

The script used the following columns to perform the estimates:

- Channel Framework ID (REF_ALL_PROJ_ID), estimated end date or stop date (Estend or 1 Jan FY/STOPDAT)

- actual cubic yards or equivalent cubic yards (Actual CY or Eq_cy_yd)

- actual cost or total bid (Actual Cst or Tot Bid).

To identify the project's name and district, the three following text columns were joined in the data:

- the district code (DISTCODE)

- the district the work was performed for in-house projects (DONE_FOR)

- project name (JOBNAME).

Projects containing a short time interval, large quantities, and few events had either their beginning or end date manually modified to provide a more appropriate annual shoaling rate.

The script was written so that the first project record was used as the start date for averaging purposes and the final record as the end date; all the remaining dredged volumes records were then averaged over this time period with the first being excluded to produce an annual average. There were 90 projects with three or more dredging records for the NAD contracted and in-house consolidated project data. 


\section{A.4 Next steps}

New work was not identified in the DIS; all data were assumed to represent O\&M dredging. These data should be closely reviewed and New Work dredging removed from average shoaling rate calculations in future analyses.

RSM contacts in each District were asked to provide the disposal location in the form of a unique four-digit channel framework disposal area code for each project that would be added to the CRSB. Each District's point of contact was provided with the DIS and channel framework disposal area code spreadsheets in June 2013. To date (July 2013), these data are not available. From the dredging records and the above-described manual data entries for Channel Framework ID, a dredged location, date, cubic yard, and ultimate placement can be defined. The Districts should have a knowledgeable contact determine and input the disposal area ID into the DIS spreadsheet. This cradle-to-grave connection for each individual project will allow for shoaling rate estimations to be input into SBAS and provide an accurate and complete picture of the recent project history. This will also allow for project history cards to be developed for each project.

District data sets go further back in time and could be extremely useful, but developing a total history was not possible within the limited duration of this study. However, a follow-on task to develop a database of historical dredging records for NAD would be extremely valuable for RSM.

\section{A.5 Dredging data resources}

The following web resources can be utilized to locate projects, channels, aliases, and placement areas:

- The Digital Project Notebook includes drawings of all authorized USACE projects: $\underline{h t t p: / / m a p s . c r r e l . u s a c e . a r m y . m i l: 7778 / a p e x / f ? p=683: 14: 0:: N O ~}$

- CE-Dredge has geo-referenced GIS locations of channels and disposal areas: $\underline{\text { http://ce-dredge.usace.army.mil/Maps.aspx }}$

- GeoPlatform is a web map that is based on the NCF service and can be used for locating channels by their Channel Framework ID. To locate a channel, click on the query tool located under the mapping tab, then use the Project ID query. If the channel is contained in the NCF, it will show the location once the channel ID is input into the query. 


\section{A.6 Matlab code}

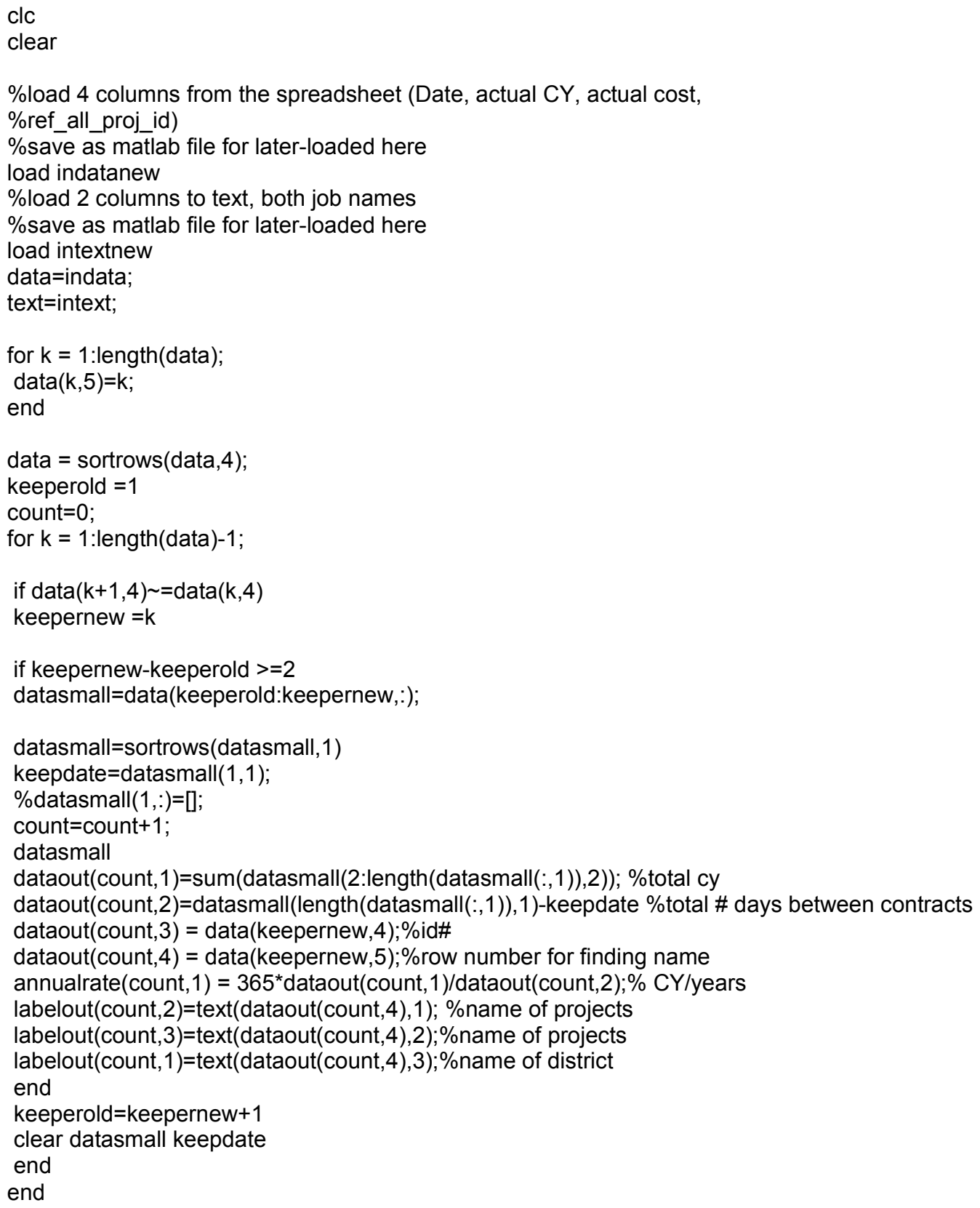

clc

clear

\%load 4 columns from the spreadsheet (Date, actual CY, actual cost,

$\%$ ref_all_proj_id)

$\%$ save as matlab file for later-loaded here

load indatanew

\%load 2 columns to text, both job names

$\%$ save as matlab file for later-loaded here

load intextnew

data=indata;

text=intext;

for $\mathrm{k}=1$ :length(data);

data $(k, 5)=k$;

end

data $=$ sortrows $($ data, 4$)$;

keeperold $=1$

count $=0$;

for $\mathrm{k}=1$ :length(data) -1 ;

if data $(\mathrm{k}+1,4) \sim=$ data $(\mathrm{k}, 4)$

keepernew $=\mathrm{k}$

if keepernew-keeperold $>=2$

datasmall=data(keeperold:keepernew,:);

datasmall=sortrows(datasmall, 1 )

keepdate $=$ datasmall $(1,1)$;

$\%$ datasmall $(1,:)=[]$;

count=count +1 ;

datasmall

dataout(count, 1 )=sum(datasmall(2:length(datasmall(:,1)),2)); \%total cy

dataout(count,2)=datasmall(length(datasmall(:,1)),1)-keepdate \%total \# days between contracts

dataout $($ count,3) $=$ data $($ keepernew, 4$) ; \%$ id\#

dataout $($ count,4) = data(keepernew,5);\%row number for finding name

annualrate (count, 1$)=365^{*}$ dataout $($ count, 1$) /$ dataout(count, 2$) ; \%$ CY/years

labelout(count,2)=text(dataout(count,4),1); \%name of projects

labelout(count,3)=text(dataout(count,4),2);\%name of projects

labelout(count,1)=text(dataout(count,4),3);\%name of district

end

keeperold=keepernew +1

clear datasmall keepdate

end

end 
The public reporting burden for this collection of information is estimated to average 1 hour per response, including the time for reviewing instructions, searching existing data sources, gathering and maintaining the data needed, and completing and reviewing the collection of information. Send comments regarding this burden estimate or any other aspect of this collection of information, including suggestions for reducing the burden, to Department of Defense, Washington Headquarters Services, Directorate for Information Operations and Reports (0704-0188), 1215 Jefferson Davis Highway, Suite 1204, Arlington, VA 22202-4302. Respondents should be aware that notwithstanding any other provision of law, no person shall be subject to any penalty for failing to comply with a collection of information if it does not display a currently valid OMB control number. PLEASE DO NOT RETURN YOUR FORM TO THE ABOVE ADDRESS.

3. DATES COVERED (From - To) 2012-2014

\begin{tabular}{l|l}
$\begin{array}{l}\text { 1. REPORT DATE } \\
\text { March } 2015\end{array}$ & $\begin{array}{l}\text { 2. REPORT TYPE } \\
\text { Special Report }\end{array}$ \\
\hline
\end{tabular}

4. TITLE AND SUBTITLE

Conceptual Regional Sediment Budget for USACE North Atlantic Division

\section{AUTHOR(S)}

Julie Dean Rosati, Ashley E. Frey, Alison Sleath Grzegorzewski, Coraggio K. Maglio, Andrew Morang, Robert C. Thomas

\section{5a. CONTRACT NUMBER \\ n/a}

\author{
5b. GRANT NUMBER \\ n/a
}

5c. PROGRAM ELEMENT NUMBER

n/a

5d. PROJECT NUMBER

$n / a$

\section{5e. TASK NUMBER}

$\mathrm{n} / \mathrm{a}$

5f. WORK UNIT NUMBER

n/a

\section{PERFORMING ORGANIZATION REPORT NUMBER}

Coastal and Hydraulics Laboratory

U.S. Army Engineer Research and Development Center

3909 Halls Ferry Road, Vicksburg, MS 39180-6199

\section{SPONSORING/MONITORING AGENCY NAME(S) AND ADDRESS(ES)}

U.S. Army Engineer North Atlantic Division

302 General Lee Avenue

Brooklyn, NY 11252

\section{DISTRIBUTION/AVAILABILITY STATEMENT}

Approved for public release; distribution is unlimited.

\section{SUPPLEMENTARY NOTES}

\section{ABSTRACT}

This report documents development of a Conceptual Regional Sediment Budget (CRSB) for the US Army Corps of Engineers (USACE) North Atlantic Division (NAD). The NAD requested preparation of a CRSB as part of the post-Hurricane Sandy assessment to provide information about sediment sources and opportunities for strategic placement of sediment within the Division. Development of a detailed working sediment budget is fundamental to better sediment management. A conceptual sediment budget is the first phase in development of the working budget, and is intended to provide a general framework based on existing transport information from which a more detailed sediment budget can be later prepared based on rigorous data analysis and numerical modeling. For this CRSB, existing literature and databases were reviewed and analyzed to characterize sediment transport pathways and magnitudes, and morphologic zones of erosion and accretion. The CRSB highlights areas with data gaps, conflicts in existing budgets, and opportunities for better sediment management within the NAD and is available via a Geographic Information System (GIS) portal.

\section{SUBJECT TERMS}

Accretion

Erosion

16. SECURITY CLASSIFICATION OF:

\begin{tabular}{|l|l|l|}
\hline a. REPORT & b. ABSTRACT & c. THIS PAGE \\
Unclassified & Unclassified & Unclassified
\end{tabular}

Hurricane Sandy

Regional Sediment Management

Sediment Budget

17. LIMITATION OF ABSTRACT

Unclassified
18. NUMBER OF PAGES
Sediment Transport

Strategic Placement 19a. NAME OF RESPONSIBLE PERSON

Julie Dean Rosati

19b. TELEPHONE NUMBER (Include area code) 202-761-1850 